Ewelina Kina*

ROZDZIA $ヒ$ VI

\title{
Rola technologii informacyjno-komunikacyjnych i sieci społecznych w kształtowaniu wartości kapitału ludzkiego
}

\section{Wstęp}

Paradygmat gospodarki opartej na wiedzy (GOW) stanowi jedno z najciekawszych zjawisk we współczesnym świecie i od ponad dekady jest „obiektem” zainteresowań badaczy różnych dziedzin nauki. Uderzenie ,trzeciej fali”" okazało się na tyle doniosłe w swoich skutkach, że spowodowało praktycznie całkowitą reorientację współczesnej gospodarki, mającą swój wyraz w przechodzeniu od gospodarki materiałochłonnej do innowacjochłonnej. W główniej mierze transformacja ta została spowodowana wzrostem znaczenia i roli informacji oraz tym, co jest z nią w stanie zrobić człowiek wykorzystując swój intelekt - wiedzą. Wiedza staje się najcenniejszym kapitałem. Poprzez świadome użycie terminu „kapitał” wiedza zostaje podniesiona do kategorii, która przy odpowiednim zastosowaniu przynosi właścicielowi dochód oraz ma zdolność pomnażania wartości. Stanowi czynnik wytwórczy używany do zwiększania produktywności innych zasobów ${ }^{2}$.

Powstało wiele opracowań o tym, czym jest gospodarka oparta na wiedzy, jak należy ją rozumieć i w jaki sposób można ją budować. Warto jednak zwrócić uwagę, chociaż w sposób syntetyczny na pewne cechy, czynniki, czy uwarunkowania, stanowiące jej trzon, a bez których wyjaśnienie idei jej funkcjonowania jest niemożliwe. Niniejsze opracowanie nie ma bezpośrednio na celu prezen-

\footnotetext{
* Asystent, Katedra Gospodarki Regionalnej i Środowiska, Wydział Ekonomiczno-Socjologiczny, Uniwersytet Łódzki. E-mail: ewelina_kina@uni.lodz.pl

${ }^{1}$ Sformułowanie ,trzecia fala” zostało użyte za Alvinem Tofflerem, którego słynna teoria fal technologicznych okazała się punktem wyjścia do analizy współczesnych przemian społecznogospodarczych.

${ }^{2}$ Definicja terminu ,kapitał” opracowana na podstawie: The Oxford Dictionary for the Business World, Oxford University Press, 1993, s. 117.
} 
tacji podejść do definiowania samego pojęcia gospodarki opartej na wiedzy, jednak by przeprowadzić spójny, kompleksowy i zrozumiały wywód w analizowanym temacie konieczne jest odwołanie się do jej ogólnej istoty. Docelowa analiza będzie bowiem dotyczyła podstawowych, konstytuujących ją zagadnień.

Koncepcja gospodarki opartej na wiedzy to wizja pewnego ładu społecznogospodarczego, w którym główną siłę napędową wzrostu, jak i rozwoju stanowi tworzenie oraz umiejętne wykorzystanie wiedzy. Najogólniej, problematyka gospodarki opartej na wiedzy obejmuje zagadnienia kształtowania się nowych struktur gospodarki wywołanych rozwojem szeroko rozumianej wiedzy. W licznych pracach podejmujących temat GOW można spotkać różne ujęcia tego hasła oraz różne jego zakresy ${ }^{3}$. Bez względu na różnorodność owych podejść, w centrum uwagi zagadnienia cały czas pozostają kwestie oddziaływania wiedzy na rozwój gospodarki. Oczywiście problematyka ta nie jest nowa, ponieważ od zawsze to właśnie wiedza stanowiła podstawowy czynnik sprawczy rozwoju. Jednak dopiero w koncepcji GOW została „wyraźnie wykrystalizowana rola wiedzy jako głównego, endogenicznego czynnika, kształtującego strukturę produkcji i postęp gospodarczy na etapie zaawansowanego rozwoju społecznogospodarczego ${ }^{4}$.” Jak zauważa P. Drucker „Nie możesz wygrać z konkurencją

${ }^{3} \mathrm{~W}$ ujęciu makroekonomicznym (1) GOW ,jest nie do końca sprecyzowaną wizją gospodarki - gospodarki, której istnienie warunkuje umiejętność efektywnego wykorzystania wiedzy na poziomie jednostek, organizacji, regionów i całych społeczeństw" (Instytut Zarządzania Wiedzą w Krakowie, Gospodarka oparta na wiedzy - stan, diagnoza i wnioski dla Polski, Warszawa-Kraków 2002, za: B. Onak-Szczepanik, Budowa gospodarki opartej na wiedzy w Polsce $w$ kontekście integracji z Uniq Europejska [w:] Konkurencyjność rynku pracy i jego podmiotów, D. Kopycińska (red.), Wydawnictwo Naukowe Katedry Mikroekonomii Uniwersytetu Szczecińskiego, Szczecin 2005, s. 33); ,to taka gospodarka, która bezpośrednio bazuje na produkcji, dystrybucji i stosowaniu wiedzy i informacj" (OECD, The Knowledge - Based Economy, OECD / GD (96) 102, za: B. Onak-Szczepanik, Budowa gospodarki opartej na wiedzy w Polsce $w$ kontekście integracji z Uniq Europejska [w:] Konkurencyjność rynku pracy i jego podmiotów, D. Kopycińska (red.), Wydawnictwo Naukowe Katedry Mikroekonomii Uniwersytetu Szczecińskiego, Szczecin 2005, s. 33); tego rodzaju gospodarka stanowi taki porządek ekonomiczny, w którym to właśnie wiedza, a nie pozostałe czynniki produkcji, są kluczowym zasobem w gospodarce (P. F. Drucker, The Age of Social Transformation, The Atlantic Monthly, November 1994, za: M. Kolarz, Znaczenie wiedzy $i$ kapitału intelektualnego we wspótczesnej gospodarce i organizacji [w:] Kapitat ludzki w dobie integracji i globalizacji, B. Kożusznik (red.), Wydawnictwo Uniwersytetu Śląskiego, Katowice 2005, s. 81-82).

W ujęciu mikroekonomicznym (2) GOW to ,gospodarka, w której działa wiele przedsiębiorstw, opierających przewagę konkurencyjną na wiedzy" (K. Śliwińska, A. Dewalska-Opitek, Gospodarka oparta na wiedzy. Stan i perspektywy rozwoju w Polsce [w:] Gospodarka oparta na wiedzy, I. K. Hejduk, J. Korczak (red.), Wydawnictwo Uczelniane Politechniki Koszalińskiej, Koszalin 2006, s. 31-32).

${ }^{4}$ Z. Chojnicki, Wiedza dla gospodarki w perspektywie OECD [w:] Gospodarka oparta na wiedzy - wyzwania dla Polski XXI wieku, A. Kukliński (red.), KBN, Warszawa 2001, s. 80. 
dzisiaj, dysponując wczorajszą wiedzą". Wzrost wartości wiedzy obserwowany jest w gospodarkach krajów rozwiniętych od około połowy lat 50. XX wieku, nie dziwi zatem, że zarówno teoretycy, jak i praktycy wypracowali do tej pory wiele różnorodnych podejść do definiowania oraz klasyfikowania tego pojęcia. Najczęściej spotykane jest rozróżnienie na szerokie i wąskie ujęcie tej kategorii. Według pierwszego z nich wiedza to „zbiór informacji, poglądów i wierzeń, którym przypisuje się wartości poznawcze bądź praktyczne, natomiast w węższym znaczeniu to ogół wiarygodnych informacji o rzeczywistości wraz z umiejętnością ich wykorzystania" ". Z kolei OECD, z ekonomicznego punktu widzenia, wyróżnia dwa ujęcia wiedzy: w postaci informacji (1) i aktywów (2) ${ }^{7}$. Pierwsze ujęcie może być traktowane jako zbieżne $\mathrm{z}$ wcześniej prezentowanym wąskim podejściem do określania wiedzy - jest ona tu rozpatrywana w postaci informacji, które po odpowiednim przetworzeniu mają zostać wykorzystane do podejmowania racjonalnych decyzji ekonomicznych (nacisk kładziony jest głównie na procesy zbierania i transformacji informacji, jako podstawy do tworzenia wiedzy). W ujęciu drugim wiedza stanowi aktywa, które biorą udział w procesach produkcji ${ }^{8}$. Wśród często spotykanych klasyfikacji wiedzy można spotkać jej podział na jawną (formalną) (explicite knowledge) oraz ukrytą (cichą) (tacit knowledge). Wiedza jawna jest usystematyzowana, jasno sprecyzowana, możliwa do przedstawienia za pomocą słów, liczb itp" ${ }^{9}$. Jest to inaczej wiedza skodyfikowana (codified knowledge) - „zapisana”, którą można przemieszczać i przechowywać $\mathrm{w}$ różnej formie ${ }^{10}$. Wiedza ukryta natomiast, to wiedza utrwalona w podświadomości, trudna bądź niemożliwa do skodyfikowania,

${ }^{5}$ S. Kwiatkowski, N. M. Sharif, Intellectual Entrepreneurship and Courage to Act, Publishing House of Leon Kozminsky Academy of Entrepreneurship and Management, Warsaw 2005, p. 142.

${ }^{6}$ L. Zienkowski, Gospodarka oparta na wiedzy - mit czy rzeczywistość? [w:] Wiedza a wzrost gospodarczy, L. Zienkowski (red.), Wydawnictwo SCHOLAR, Warszawa 2003, s. 16.

${ }^{7}$ Knowledge management in the learning society. Education and skills. OECD 2000, Paris, s. $12-13$.

${ }^{8} \mathrm{~W}$ tym ujęciu wiedza może być traktowana jako dobro prywatne i jako towar może być przedmiotem obrotu rynkowego, bądź dobro publiczne. Różnicuje ją głównie poziom dostępności dla użytkowników i możliwość jej wielorazowego i/lub równoczesnego wykorzystania przez nich. (Z. Chojnacki, Wiedza dla gospodarki w perspektywie OECD [w:] Gospodarka Oparta na Wiedzy - wyzwania dla Polski XXI wieku, A. Kukliński (red.), KBN, Warszawa 2001, s. 81-82.)

${ }^{9}$ M. Kolarz, Znaczenie wiedzy i kapitału intelektualnego we współczesnej gospodarce i organizacji [w:] Kapitat ludzki w dobie integracji i globalizacji, B. Kożusznik (red.), Wydawnictwo Uniwersytetu Śląskiego, Katowice 2005, s. 80.

${ }^{10}$ M. Markowska, Zróżnicowanie europejskiej przestrzeni regionalnej w świetle koncepcji gospodarki opartej na wiedzy [w:] Gospodarka lokalna i regionalna w teorii i praktyce, D. Strahl (red.), Prace Naukowe Akademii Ekonomicznej im. O. Langego we Wrocławiu, Nr 1161, Wydawnictwo Akademii Ekonomicznej im. O. Langego we Wrocławiu, Wrocław 2007, s. 36. 
przekazywana w procesie socjalizacji wiedzy ${ }^{11}$. Wiedza ta jest wykorzystywana w życiu codziennym, jednak trudno ją przekazać, gdyż trudno wyjaśnić istotę jej istnienia. To wiedza fachowa, specjalistyczna, którą posiadają tylko niektórzy pracownicy - stanowi ona zdecydowanie ważniejsze źródło przewagi konkurencyjnej od wiedzy jawnej ${ }^{12}$. Wreszcie pozostaje najpopularniejszy podział wiedzy - funkcjonalny ${ }^{13}$, dokonywany $\mathrm{w}$ zależności od etapu procesu zarządzania, w którym wiedza jest wykorzystywana.

Jednak sama wiedza, mimo że w teorii stanowi podstawę i cechę konstytutywną gospodarki opartej na wiedzy, aby mogła zostać efektywnie wykorzystana potrzebuje czynnika ludzkiego. Dopiero osadzona w ludzkim umyśle może generować jakąkolwiek wartość i przynosić korzyści dla wzrostu i rozwoju społeczno-gospodarczego. Wiedza musi zatem zostać niejako zmaterializowana w ludziach. Obecność człowieka jest warunkiem koniecznym zarówno do powstania wiedzy, jak i do jej zastosowania. Inaczej mówiąc, by skutecznie tworzyć, wykorzystać i generować korzyści płynące z wiedzy niezbędna jest odpowiednia jakość kapitału ludzkiego. To właśnie coraz większe znaczenie wiedzy w poszczególnych procesach gospodarczych zaczęło powodować wzrost istotności kapitału ludzkiego w generowaniu procesów rozwoju. Doprowadziło to do sytuacji, w której właśnie ten rodzaj kapitału, rozumiany najprościej jako ucieleśniona w człowieku wiedza, wskazywany jest obecnie za najistotniejszy, z punktu widzenia budowania przewag konkurencyjnych w gospodarce opartej na wiedzy. Człowiek jest jednak istotą, która funkcjonuje w określonym środowisku, wśród danej społeczności, w której wytwarzają się pewne normy, relacje, zaufanie $\mathrm{i}$ ani jego działania, ani dalszy rozwój nie może odbywać się w oderwaniu od tego otoczenia. Dzieje się tak między innymi dlatego, że rozwój człowieka odbywa się głównie dzięki procesowi uczenia się, a ten z kolei jest procesem zbio-

${ }^{11}$ M. Kolarz, Znaczenie wiedzy i kapitału intelektualnego we wspótczesnej gospodarce $i$ organizacji [w:] Kapitat ludzki w dobie integracji i globalizacji, B. Kożusznik (red.), Wydawnictwo Uniwersytetu Śląskiego, Katowice 2005, s. 80.

${ }^{12}$ R. Przybyszewski, Kapitat ludzki w procesie ksztaltowania gospodarki opartej na wiedzy, Wydawnictwo Difin, Warszawa 2007, s. 30-31.

${ }^{13}$ Klasyczne ujęcie podziału funkcjonalnego wyróżnia 4 podstawowe rodzaje wiedzy: (1) wiedzieć co (know-what) - wiedza na temat faktów, zdarza się, że jest identyfikowana ze zwykłą informacją; (2) wiedzieć dlaczego (know-why) - wiedza na temat reguł panujących w naturze, czy społeczeństwie; (3) wiedzieć jak (know-how) - dotyczy umiejętności pozwalających na zrobienie czegoś, to wiedza ekspertów gromadzona głównie w postaci ich doświadczenia, jej transfer jest trudny, a publiczny dostęp do niej stosunkowo ograniczony; (4) wiedzieć kto (know-who) - to informacje i relacje o tym, kto co wie. Ten rodzaj wiedzy dotyczy również społecznych zdolności do współpracy i komunikacji z ekspertami.

Podział ten został uzupełniony przez kolejnych badaczy o następne rodzaje wiedzy, takie jak: wiedzieć kiedy, wiedzieć który, znać relacje, wiedzieć gdzie, wiedzieć czy. (Szerzej: Z. Przygodzki, Region wiedzy - wiedza i kapital ludzki a rozwój regionu [w:] Region w gospodarce opartej na wiedzy. Kapitat ludzki - innowacje - korporacje transnarodowe, A. Nowakowska, Z. Przygodzki, M.E. Sokołowicz (red.), Wydawnictwo Difin, Warszawa 2011, s. 17-18. 
rowym, społecznym i dokonuje się poprzez wzajemne oddziaływanie i współpracę różnych podmiotów. W szerszej perspektywie odwołuje się zatem do kategorii kapitału społecznego, który dzięki współpracy i budowaniu relacji generuje wartość dodaną i jednocześnie tworzy przyjazne środowisko, ,żyzne podłoże" do tworzenia nowej wiedzy - tym samym kapitału ludzkiego o wyższej wartości.

Kapitał ludzki i związana z nim kategoria wiedzy stanowią jednak tylko jeden z filarów gospodarki opartej na wiedzy. Jej rozwój jest również ściśle związany z procesem informatyzacji i tzw. rewolucją informacyjną. To właśnie leżące $\mathrm{u}$ jej podstaw technologie informacyjno-komunikacyjne (Information and Communication Technologies - ICT) wskazywane są jako jeden z głównych czynników napędzających zmiany ekonomiczne, polityczne i cywilizacyjne współczesnego świata. Początkowo istotność tego czynnika dla GOW utożsamiana była głównie z usprawnienie procesów komunikacji i zwiększeniem szybkości przekazywania informacji. Współcześnie jednak, dzięki ciągłemu rozwojowi nowoczesnych technologii, owe procesy komunikacji odbywają się nie tylko szybciej i sprawniej, ale często nabierają całkiem nowego oblicza i wymiaru, przenosząc się ze świata rzeczywistego w świat wirtualny. Stwarzają nowe możliwości w zakresie nawiązania współpracy, wymiany doświadczeń, dzielenia się swoją wiedza, ale dodatkowo tworzą również nowe środowisko do budowania zaufania między jego uczestnikami. Specyficzne cechy tego środowiska mogą powodować sytuacje, w których ludzie wykazują większą skłonność w zakresie wymiany doświadczeń, informacji, dzielenia się pomysłami, ideami. Technologie te mogą sprzyjać większej aktywności, chęci współpracy, zaangażowania się w realizację określonego celu. W konsekwencji zatem, głównie poprzez wpływ na elementy kapitału społecznego, mogą wpływać na sam proces powstawania i dyfuzji wiedzy, stanowiącej o wartości kapitału ludzkiego. Usprawniają bowiem procesy komunikacji, dzięki budowaniu zaufania wśród wspólnot wirtualnych, wspomaganiu tworzenia szerokich sieci współpracy. Przykładem takiego rodzaju zaawansowanych narzędzi informacyjno-komunikacyjnych wywierających duży wpływ na współczesne procesy komunikacji są portale społecznościowe. Zaczęły one zdobywać popularność w latach 90 . XX wieku i początkowo dawały możliwość kontaktu jego użytkownikom z rodziną bądź znajomymi ze szkoły, poprzez takie aktywności jak: stworzenie własnego profilu, wysyłanie wiadomości do ludzi ze swojej "listy znajomych" oraz wyszukiwanie wśród pozostałych użytkowników ludzi o podobnych zainteresowaniach. W najprostszym ujęciu portale społecznościowe to specyficzne serwisy internetowe, które istnieją w oparciu o zgromadzoną wokół nich społeczność. Z czasem zaczęły się one rozwijać na bardzo dużą skalę, stając się jednym z głównych narzędzi komunikacji człowieka XXI wieku. 
W oparciu o zarysowany powyżej tok rozumowania i wspołzależności występujące pomiędzy elementami kapitału społeczny i kapitału ludzkiego postawiono tezę, że kapitał społeczny może wpływać na wartość kapitału ludzkiego, m.in. poprzez modyfikację procesów komunikacji. Przyjęto założenie, że na skuteczność przepływów informacji, jak i na dyfuzję wiedzy wpływają istniejące sieci społecznej współpracy i poziom wzajemnego zaufania. Pamiętając, że współczesne procesy komunikacji międzyludzkiej są zdominowane przez nowoczesną infrastrukturę komunikacyjną, w pracy skoncentrowano uwagę na wykazaniu, że technologie ICT (w szczególności poddane badaniu portale społecznościowe) można traktować jako narzędzia, wykorzystywane do inwestowania we wzrost wartości kapitału ludzkiego. Zatem w tym przypadku inwestując w pomnażanie wartości kapitału społecznego można jednocześnie skutecznie inwestować we wzrost wartości kapitału ludzkiego.

Realizacji przyjętych założeń podporządkowana została konstrukcja pracy. W pierwszej kolejności, odwołując się do ogólnej koncepcji kapitału ludzkiego i społecznego, podjęto próbę identyfikacji współzależności pomiędzy czynnikami tworzącymi wartość obu kapitałów. Szczególna uwaga została zwrócona na wpływ zaufania i sieci współpracy na przepływ informacji oraz dyfuzję wiedzy. W dalszej kolejności zostały wskazane nowe możliwości, jakie daje wykorzystanie narzędzi informacyjno-komunikacyjnych w zakresie organizacji procesów komunikacji i dyfuzji wiedzy.

\section{Komplementarność i współzależność inwestycji w wartość kapitału ludzkiego i społecznego}

Coraz większe zainteresowanie, $\mathrm{w}$ ciągu ostatnich kilkudziesięciu lat, ideą kapitału ludzkiego i społecznego spowodowane jest między innymi tym, że hasła te okazały się bardzo użyteczną i uniwersalną kategorią analityczną, która wreszcie dała nadzieję na właściwe uchwycenie oraz wyjaśnienie wpływu społecznych i kulturowych relacji na procesy ekonomiczne czy polityczne. Część ekonomistów i socjologów zwróciła uwagę, że „kultura ma znaczenie”, a wszystkie zjawiska i procesy ekonomiczne stanowią nieodłączną część życia społecznego ${ }^{14}$. F. Fukuyama, amerykański politolog i ekonomista przyznaje

${ }^{14}$ Por. L. E. Harrison, S. P. Huntington (red.), Kultura ma znaczenie, Wydawnictwo Zysk i S-ka, Poznań 2003; T. Kaźmierczak, Kapitał społeczny a rozwój społeczno-ekonomiczny - przeglad podejść [w:] Kapitat społeczny. Ekonomia społeczna, T. Kaźmierczak, M. Rymsza (red.), Instytut Spraw Publicznych, Warszawa 2007, s. 40-62; T. Michalczyk, S. Musioł, Kapitat ludzki i spoleczny a rozwój społeczno-ekonomiczny w świetle nowej analizy instytucjonalnej [w:] Kapitaty ludzkie i spoleczne a konkurencyjność regionów, M.S. Szczepański, K. Bierwiaczonek, T. Nawrocki (red.), Wydawnictwo Uniwersytetu Śląskiego, Katowice 2008, s. 60-73. 
nawet, że pominięcie czynników społecznych i kulturowych „stanowi o ubóstwie współczesnego dyskursu ekonomicznego" ${ }^{15}$. Początkowo zwrócono uwage na fakt, że produktywność zarówno jednostek, jak i zbiorowości nie zależy jedynie od wielkości dostępnego kapitału fizycznego bądź finansowego, ale jest również uzależniona od takich czynników, jak kwalifikacje czy kompetencje, które decydują o możliwościach i sposobach wykorzystania klasycznych czynników produkcji. Przekonanie to stało się podstawą teorii kapitału ludzkiego ${ }^{16}$. $\mathrm{Z}$ czasem jednak okazało się, że takie podejście do kompleksowego wyjaśniania wzrostu gospodarczego jest niewystarczające, gdyż każde działanie człowieka osadzone jest w określonym terytorium, społeczności, która wykształciła swoją kulturę, pewne normy i wartości wpływające na zjawiska ekonomiczne. Poza tym, kategoria kapitału ludzkiego jest ściśle powiązana z konkretnym człowiekiem, indywidualną jednostką, a działalność pojedynczego człowieka, nawet najbardziej kreatywnego, nie przynosi znaczących rezultatów jeśli nie posiada on dostępu do innych ludzi. Kapitał ten jest zdecydowanie bardziej produktywny i daje większe korzyści, gdy poszczególne jednostki potrafią, w duchu współpracy i zaangażowania się w realizację wspólnych celów, połączyć swoje kompetencji i indywidualne specyficzne zasoby. To wspólne działanie jest właśnie podstawą kapitału społecznego ${ }^{17}$.

Opracowanie nie ma na celu szerokiego i dokładnego przedstawienia ujęć teoretycznych obu terminów (kapitału ludzkiego i społecznego), jednak dla lepszego zrozumienia zależności występujących między nimi, konieczne jest chociaż podstawowe odwołanie się do ich kluczowych elementów.

Za pierwszych, którzy w latach 60 . XX wieku, wprowadzili na stałe do literatury ekonomicznej pojęcie kapitału ludzkiego, uznaje się T. W. Schultza i G.S. Beckera $^{18}$. Drugi $\mathrm{z}$ autorów wprowadził dodatkowo pojęcie inwestowania w kapitał ludzki, jako alokację zasobów, która wpływa na przyszłe realne dochody. Próbował on udowodnić ścisłe powiązania oddziaływania czynnika ludzkiego, wyrażonego poziomem jego wykształcenia, na wzrost poziomu jego do-

${ }^{15}$ F. Fukuyama, Social capital and global economy, Foreign Affairs 1995, 74 (5), s. 101.

${ }^{16}$ Szerzej: G. S. Becker, Human capital: A theoretical and empirical analysis with special reference to education, Columbia University Press, New York 1975.

${ }^{17}$ A. Jewtuchowicz, Terytorium $i$ wspótczesne dylematy jego rozwoju, Wydawnictwo Uniwersytetu Łódzkiego, Łódź 2005, s. 119.

${ }^{18}$ G. Wronowska, Koncepcja kapitału ludzkiego - ujęcie historyczne [w:] Teoretyczne aspekty gospodarowania, D. Kopycińska (red.), Katedra Mikroekonomii Uniwersytetu Szczecińskiego, Szczecin 2005 s. 121. Chociaż już dużo wcześniej część ekonomistów dostrzegła, że każdy człowiek może być traktowany jako forma kapitału, a umiejętności nabywane przez wszystkich mieszkańców kraju można uznać za część jego kapitału. Poglądy takie głosili m.in. A. Smith i J.H. von Thünen. (Szerzej: K. Cichy, K. Malaga, Kapital ludzki w modelach teorii wzrostu gospodarczego, Polskie Towarzystwo Ekonomiczne, s. 1-2, http://www.pte.pl/pliki/2/12/Kapital_ludzki_ujecie_modelowe.pdf] 
brobytu $^{19}$. Kolejni badacze, podążając kierunkiem rozważań swoich poprzedników, wprowadzali coraz to nowe elementy do teorii kapitału ludzkiego. R.E. Lucas w zaproponowanym modelu kapitału ludzkiego wyróżnił efekt jego zewnętrznej i wewnętrznej produktywności, co oznaczało, że za budowanie wartości jednostki (kapitału ludzkiego) nie jest odpowiedzialna jedynie ona sama, ale jej wartość zależy również od innych jednostek: otoczenia oraz środowiska. Inwestycje w wiedzę (kapitał ludzki) wymagają innego, niż indywidualistyczna orientacja gospodarki kapitalistycznej, kontekstu społecznego ${ }^{20}$.

Samo pojęcie jest trudne do precyzyjnego zdefiniowania. Najprostsze, a zarazem najogólniejsze ujęcie sprowadza się do określenia go jako zasobu wiedzy i umiejętności człowieka ${ }^{21}$. Jest to potencjał tkwiący w każdej osobie, składający się z wielu elementów, takich jak: wykształcenie, wiedza, stan zdrowia, energia, umiejętności i zdolności, a także motywacja czy wyznawane wartości ${ }^{22}$. Oprócz tych podstawowych, najczęściej wyróżnianych elementów, wskazuje się również na przedsiębiorczość, kreatywność i otwartość na wiedzę ${ }^{23}$. Jeszcze szerzej definicję tę przedstawiają M. Bartnicki i J. Strużyna. Według nich kapitał ludzki tworzą takie elementy, jak: motywacja, kompetentność i zręczność intelektualna. Pod pojęciem motywacji należy rozumieć chęci do działania, predyspozycje osobowościowe do określonych zachowań, zaangażowanie w procesy organizacyjne, skłonność do zachowań etycznych, wiedzę organizacyjną, przywództwo menedżerskie. W określeniu kompetentność zawarte są takie właściwości jak: umiejętności praktyczne (biegłość, fachowość), wiedza teoretyczna, talenty. Z kolei zręczność intelektualna określana jest przez poziom innowacyjności jednostki, zdolność do naśladowania, przedsiębiorczość, skłonność do zmian² R. Domański w swojej definicji dodatkowo podkreśla możliwość powiększania

${ }^{19}$ G. Becker, Ekonomiczna teoria zachowań ludzkich, Wydawnictwo Naukowe PWN, Warszawa 1990, s. 44-54.

${ }^{20}$ Szerzej: Z. Przygodzki, Region wiedzy - wiedza i kapitat ludzki a rozwój regionu [w:] Region $w$ gospodarce opartej na wiedzy. Kapitat ludzki - innowacje - korporacje transnarodowe, A. Nowakowska, Z. Przygodzki, M.E. Sokołowicz (red.), Wydawnictwo Difin, Warszawa 2011, s. 46,49 .

${ }^{21}$ J. Grodzicki, Rola kapitalu ludzkiego w rozwoju gospodarki globalnej, Wydawnictwo Uniwersytetu Gdańskiego, Gdańsk 2003, s. 46.

${ }^{22}$ W. Jarecki, Koncepcja kapitatu ludzkiego [w:] Kapitał ludzki w gospodarce, D. Kopycińska (red.), Polskie Towarzystwo Ekonomiczne, Szczecin 2003, s. 29.

${ }^{23}$ Por. A. B. Czyżewski, M. Góralczyk-Modzelewska, E. Saganowska, M. Wojciechowska, Regionalne zróżnicowanie kapitału ludzkiego w Polsce, Z Prac Zakładu Badań StatystycznoEkonomicznych, zeszyt 277, Zakład Badań Statystyczno-Ekonomicznych GUS i PAN, Warszawa 2001, s. 10; A. Mempel-Śnieżyk, Kapitat ludzki i kapitat spoteczny w gospodarce opartej na wiedzy [w:] Nowe paradygmaty gospodarki przestrzennej, K. Miszczak, Z. Przybyła (red.), Biuletyn KPZK PAN, zeszyt 236, Warszawa 2008, s. 109-114.

${ }^{24}$ M. Bratnicki, J. Strużyna (red.) Przedsiębiorczość i kapitat intelektualny, Wydawnictwo Uczelniane Akademii Ekonomicznej im. K. Adamieckiego w Katowicach, Katowice 2001, s. 69-70. 
kapitału ludzkiego poprzez inwestycje w człowieka ${ }^{25}$. Jest to niezwykle istotna cecha, szczególnie w sytuacji gdy dominującą siłą napędową rozwoju gospodarczego, zarówno w skali lokalnej, regionalnej czy globalnej, jest zdolność ciągłego podnoszenia swoich kwalifikacji i zdobywania nowych umiejętności przez wszystkich członków społeczeństwa ${ }^{26}$. Inwestycje w czynniki decydujące o wartości kapitału ludzkiego (jego elementy) mogą przybierać różną postać. Mogą być realizowane za pomocą narzędzi bezpośrednich oraz pośrednich. Pierwsze z nich mają generować jednoznaczny efekt w postaci wzrostu ilości oraz jakości zasobów tego kapitału i koncentrują się głównie (choć nie tylko) na podnoszeniu poziomu wykształcenia. Należą do nich takie narzędzia jak: edukacja, kursy, szkolenia, kształcenie ustawiczne, ale również np. nakłady na ochronę zdrowia. W przypadku drugiej grupy narzędzi wzrost poziomu kapitału ludzkiego ma być efektem ubocznym pewnych działań. Przykładami tego rodzaju narzędzi są wszelkiego rodzaju działania, mające na celu pobudzenie aktywności gospodarczej, poprzez np. wspieranie przedsiębiorczości, czy działania służące budowie społeczeństwa informacyjnego ${ }^{27}$. Istotne są zatem zarówno bezpośrednie działania skierowane do konkretnych jednostek, w celu podniesienia ich kapitału, jak i tworzenie sprzyjających warunków do jego rozwoju. Współczesne teorie kapitału ludzkiego najczęściej wskazują, że inwestycje w niego polegaja głównie na pomnażaniu zasobów wiedzy i umiejętności ${ }^{28}$. Zasoby te zwiększaja się dzięki procesowi uczenia się, a ten z kolei, jak podkreśla R. Domański, dokonuje się między innymi przez wzajemne oddziaływanie i współpracę różnych podmiotów, stając się tym samym procesem zbiorowym, a w szerszej perspektywie społecznym ${ }^{29}$. W tym miejscu, z owym kontekstem społecznym, konieczne jest wyjście poza analizę indywidualnych, osadzonych w każdym człowieku umiejętności i kompetencji.

Tak jak już zostało wspomniane wcześniej, wśród naukowców zaczęły pojawiać się wątpliwości, czy przy pomocy kapitału ludzkiego możliwe jest pełne wyjaśnienie różnic w poziomach rozwoju gospodarczego. Dla przykładu, eko-

${ }^{25}$ S. R. Domański, Kapitał ludzki i wzrost gospodarczy, Wydawnictwo Naukowe PWN, Warszawa 1993, s. 19.

${ }^{26}$ Z. Przygodzki, Znaczenie kapitału ludzkiego w budowaniu innowacyjnych regionów [w:] Budowanie zdolności innowacyjnych regionów, A. Nowakowska (red.), Wydawnictwo Uniwersytetu Łódzkiego, Łódź 2009, s. 64.

${ }^{27}$ Z. Przygodzki, Region wiedzy - wiedza i kapital ludzki a rozwój regionu [w:] Region w gospodarce opartej na wiedzy. Kapitat ludzki - innowacje - korporacje transnarodowe, A. Nowakowska, Z. Przygodzki, M.E. Sokołowicz (red.), Wydawnictwo Difin, Warszawa 2011, s. 64.

${ }^{28}$ Oczywiście wskazywane są również inwestycje w zdrowie, działania dla poprawy kondycji fizycznej i psychicznej, wpływające na zdolność ludzi do pracy oraz ich energię, wytrzymałość i długość życia. R. Domański, Kapitat ludzki $i$ wzrost gospodarczy, Wydawnictwo Naukowe PWN, Warszawa 1992, s. 19.

${ }^{29}$ R. Domański, Regionalny poziom gospodarki uczqcej się, Czasopismo Geograficzne LXXI, 2000, s. 3-4. 
nomista Glen Loury twierdził nawet, że klasyczne teorie ekonomiczne są zbyt indywidualistyczne. Skupiają się bowiem głównie na kapitale ludzkim pojedynczych jednostek i na opisie mechanizmu konkurencji, w którym wykorzystują one jedynie własne zasoby ${ }^{30}$. Autor ten co prawda nie rozwiną koncepcji kapitału społecznego, ale zwrócił uwagę na pewien niedostatek uwzględnienia „tego co społeczne" do kreowania kapitału ludzkiego.

Pojęcia kapitał społeczny po raz pierwszy użyto w 1916 roku $^{31}$, jednak dopiero w latach 80. i 90. XX wieku zostało ono upowszechnione w refleksji nad rozwojem społecznym i gospodarczym, głównie dzięki pracom Pierre'a Bourdieu i równocześnie Jamesa Colemana. Wśród jeszcze wcześniejszych źródeł, mogących stanowić inspirację dla twórców koncepcji kapitału społecznego, często wskazywane są również prace Maksa Webera ${ }^{32}$. W spostrzeżeniach Webera można odnaleźć wszystkie kluczowe elementy „współczesnej” definicji kapitału społecznego: (1) istnienie sieci relacji o charakterze nieekonomicznym, (2) specyficzne funkcje sieci relacji (usprawniającej obieg informacji i generującej zaufanie), (3) skłonność do dzielenia się informacją oraz zaufanie ${ }^{33}$. Jednak weberowskie idee dotyczące sieci społecznych zostały na długi czas zapomniane w dyskusjach o kapitale społecznym. Przez lata sam termin nie był przedmiotem głębokich rozważań i nie dorobił się precyzyjnej definicji. Dopiero w połowie lat 80. XX w., praktycznie równoległe (choć w znacznym stopniu przeciwstawne) prace P. Bourdieu i J. Colemana uważane są za początek szerokiej i często burzliwej dyskusji, nad koncepcją kapitału społecznego i jej miejscem w różnych dziedzinach nauki.

P. Bourdieu zdefiniował kapitał społeczny jako ,sumę zasobów, aktualnych i potencjalnych, które należą się jednostce lub grupie z tytułu posiadania trwałej, mniej lub bardziej zinstytucjonalizowanej sieci relacji, znajomości i wzajemnego

${ }^{30}$ Por. G. C. Loury, A dynamic theory of racial income differences [w:] P. A. Wallace, A.M. LaMond (eds.), Women, Minorities, and Employment Discrimination, MA: Heath, Lexington 1977; G. C. Loury, Intergenerational transfers and the distribution of earnings, Econometrica 1981, no. 49.

${ }^{31}$ Pojęcie to po raz pierwszy zostało użyte przez L. J. Hanifan. W pracy The Rural School Community Center została zwrócona uwaga na zagrożenie, jakie niesie dla demokracji rosnąca pasywność obywateli względem spraw lokalnych. Wzmacnianie lokalnych wspólnot oraz budowa osobistych relacji między obywatelami mogą stać się rozwiązaniem wielu problemów gospodarczych, społecznych i politycznych. (C. Trutkowski, S. Mandes, Kapitat społeczny w matych miastach, Wydawnictwo SCHOLAR, Warszawa 2005, s. 49; L. J. Hanifan, The Rural School Community Center, Annals of the American Academy of Political and Social Science, no. 67, 1916).

${ }^{32}$ Autor ten sam nigdy tego pojęcia nie użył, choć w swym eseju z 1906 roku pt. „Sekty protestanckie i duch kapitalizmu" zauważył, że sekty i kształtujący się w ich ramach specyficzny rodzaj więzi społecznej, otoczony mechanizmem kontroli nad członkami, w największym stopniu przyczyniły się do ekspansji kapitalistycznej gospodarki oraz zasad wymiany handlowej.

${ }_{33}$ C. Trigilia, Social capital and local development, European Journal of Social Theory, 4 (4) 2001, s. 429. 
uznania" ${ }^{34}$. W tym ujęciu, indywidualny potencjał związany z posiadaniem kapitału społecznego jest uzależniony od zasięgu sieci powiązań i relacji, w których dana jednostka uczestniczy i przez które posiada dostęp do określonych zasobów. Owa sieć nie jest zasobem stałym, stabilnym, narzuconym raz na zawsze przez jakieś czynniki zewnętrzne. Owszem, jest ona pochodna pewnych czynników niezależnych, dziedzicznych, związanych chociażby ze społecznym miejscem urodzenia, ale prawdziwy potencjał sieci może rozwijać się dzięki indywidualnie podejmowanym działaniom i wysiłkom oraz indywidualnym zdolnościom podtrzymywania i rozwijania relacji społecznych ${ }^{35}$. W tym ujęciu kapitał społeczny traktowany jest jako atrybut konkretnej jednostki, która sama go tworzy i wykorzystuje dzięki istnieniu wzajemnych związków między uczestnikami sieci. W członkach sieci, dzięki dostępowi do zasobów innych uczestników sieci, buduje się poczucie „kolektywnego posiadania kapitału”. Wielkość kapitału społecznego zależy zatem od kapitału ludzkiego - indywidualnych predyspozycji, umiejętności, działań i wysiłków jednostek tworzących sieć. Kapitał społeczny nie powstaje samoistnie, a jest produktem konkretnych jednostkowych lub kolektywnych strategii inwestycyjnych, realizowanych w sposób mniej lub bardziej świadomy.

Z kolei nieco inne jest powiązanie kapitału ludzkiego z kapitałem społecznym przedstawiane $\mathrm{w}$ ujęciu teoretycznym prezentowanym przez Jamesa Colemana. Kapitał społeczny jest traktowany jako zbiór zasobów zawierających się i wynikających z relacji społecznych. W zależności od rodzaju czy pochodzenia tych relacji, zasoby różnią się, a różnice te decydują o stopniu rozwoju i możliwości wykorzystania kapitału ludzkiego (umiejętnościach, wiedzy konkretnej jednostki) ${ }^{36}$. Innymi słowy, kapitał społeczny jest traktowany jako główny czynnik przesądzający o ostatecznym sposobie wykorzystania, zainwestowania kapitału ludzkiego. Zdaniem Colemana, w odróżnieniu od stanowiska Bourdieu, kapitał społeczny nie jest właściwością jednostek ani wynikiem jej konkretnych, zamierzonych działań, stanowi zaś rzeczywiste lub potencjalne zasoby, generowane tylko i wyłącznie dzięki istnieniu różnego rodzaju relacji i związków pomiędzy jednostkami ${ }^{37}$. Coleman uważał generowanie kapitału społecznego za zjawisko nieintencjonalne, będące nieplanowanym z góry efektem działań realizowanych w innym celu. Wskazywał on dodatkowo, że podstawę istnienia kapitału społecznego stanowi zaufanie do innych uczestników określonej grupy spo-

${ }^{34}$ P. Bourdieu, J.D.L. Wacquant, Zaproszenie do socjologii refleksyjnej, Oficyna Naukowa, Warszawa 2001, s. 105

${ }^{35}$ C. Trutkowski, S. Mandes, Kapitat społeczny w matych miastach, Wydawnictwo SCHOLAR, Warszawa 2005, s. 53.

${ }^{36}$ J.S. Coleman, A rational choice perspective on economic sociology [w:] Handbook of Economic Sociology, N.J Smelser, R. Swedberg (ed.), Princeton University Press, Princeton 1994, p. 300.

37 J.S. Coleman, Foundations of Social Theory, MA: The Belknap Press, Cambridge 1990, p. 302. 
łecznej. Wątek zaufania stanowił dla niego istotny element podnoszący wartość kapitału społecznego. Skłonność do łączenia się w grupy, dla realizacji określonych celów uzależniona jest od stopnia, w jakim jednostki tej grupy podzielają pewne wspólne normy, zasady i wartości, stanowiące podłoże do budowania zaufania.

Do ujęcia normatywnego kapitału społecznego odwołuje się również F. Fukuyama, dla którego przy analizie tego pojęcia istotniejsze od powiązań są określone, obowiązujące i wspólnie podzielane normy, a jego rozumienie sprowadza on do prostej definicji, według której kapitał społeczny to nieformalne normy, zachęcające do współpracy między dwoma lub więcej jednostkami. Równie mocno akcentuje przy tym znaczenie zaufania, jako kategorii mającej istotną i wymierną wartość ekonomiczną ${ }^{38}$.

Jednak za głównego sprawcę kariery pojęcia kapitału społecznego uznawany jest Robert Putnam, który swoje rozważania o tym zagadnieniu wyprowadza częściowo, choć w nieco zmodyfikowanym ujęciu od J. Colemana. W swej koncepcji kapitału społecznego zwraca również uwagę na znaczenie norm, zaufania i sieci, ale wskazuje dodatkowo na znaczącą rolę stowarzyszeń, jako ośrodków rozprzestrzeniania zaufania, norm wzajemności i gotowości do kooperacji. Putnamowska wersja tego pojęcia ma charakter zdecydowanie kolektywny. Według autora, kapitał społeczny to „takie jakości życia stowarzyszeniowego w danym społeczeństwie, jak sieci, normy oraz zaufanie - jakości te umożliwiają członkom danego społeczeństwa zwiększenie efektywności zbiorowego działania i sprawniejsze osiaganie podzielanych przez nich celów"39. Autorowi temu zawdzięczamy również wyodrębnienie dwóch różnych form kapitału społecznego: kapitału społecznego wiążącego - zbliżającego do siebie ludzi już dobrze się znających oraz kapitału społecznego pomostowego - spajającego ludzi bądź grupy wcześniej sobie obce ${ }^{40}$.

${ }^{38}$ F. Fukuyama, Zaufanie. Kapitat spoteczny a droga do dobrobytu, Wydawnictwo Naukowe PWN, Warszawa 1997, s. 20-21.

39 R. D. Putnam, Demokracja $w$ działaniu: tradycje obywatelskie we wspótczesnych Włoszech, Instytut Wydawniczy „Znak”, Fundacja im. Stefana Batorego, Kraków-Warszawa 1995, s. 56.

${ }^{40} \mathrm{~W}$ literaturze można również spotkać określenia: kapitał społeczny zamknięty i kapitał społeczny otwarty. Nazewnictwo to (bonding and bridging social capital) w rzeczywistości wprowadzili do literatury inni amerykańscy badacze, oczywiście opierając się na rozważaniach zawartych w pracy Putnama o demokracji we Włoszech: R.J. Gittell i A. Vidal. (Szerzej: R. J. Gittell i A. Vidal, Community organizing: building social capitalas a development strategy, Thousand Oaks, Sage 1998, s. 15). Niekiedy, zwłaszcza w naukach politycznych, wprowadza się również trzeci typ kapitału społecznego, który dotyczy relacji pomiędzy różnymi warstwami społecznymi w strukturach władzy. Jest on określany jako kapitał łączący (linking social capital) (M. Woolcock, The place of social capital in understanding social and economic outcomes, Canadian Journal of Policy Research 2001, t. 2, nr 1, s. 11-17). 
Definicję obszerną i niejako podsumowującą klasyczne ujęcia kapitału społecznego, przedstawia T. Kaźmierczak. Jest to „zasób jednostek, którego źródłem są sieci ich powiązań, po których krążą dobra symboliczne (informacje, wiedza, wartości, idee i inne), materialne (rzeczy, pieniądze) i emocjonalne (aprobata, szacunek, sympatia, itp.). Kapitał społeczny, warunkując wzajemność i zaufanie wpływa na gotowość podejmowania współpracy i na potencjał jej efektywności. Cechą szczególną kapitału społecznego jest to, iż pozwala on swoim dysponentom osiagać cele, które w innym przypadku nie byłyby zrealizowane w ogóle, lub wymagałyby poniesienia wyższych kosztów. Tak rozumiany kapitał społeczny nie jest dobrem publicznym, tylko „klubowym”, ponieważ nie każdy ma do niego dostęp - jedynie jednostki powiązane sieciami" ${ }^{\text {"41 }}$.

Inwestycje w kapitał społeczny mają charakter skomplikowany i trudno wskazać najlepsze oraz powszechnie akceptowalne metody ich pomiaru. Najczęściej przyjmuje się, że jedną z podstawowych form inwestycji w kapitał społeczny jest, podobnie jak w przypadku kapitału ludzkiego, edukacja. Jednak należy pamiętać, że akumulacja owego kapitału zachodzi poprzez różnego rodzaju interakcje społeczne, zaczynając od rodzinnych wzorców społecznych, poprzez nieograniczony dostęp do kultury, po świadomość obywatelską i aktywne uczestnictwo $\mathrm{w}$ organizacjach pozarządowych oraz wydarzeniach lokalnych.

Mimo, że kapitał społeczny w większości definicji nie jest rozpatrywany jako kategoria jednostkowa, ale społeczna i właśnie ta cecha jest najczęściej wskazywana jako różnicująca między nim a kapitałem ludzkim, to można wyróżnić dwa poziomy występowania efektów kapitału społecznego (uogólniając, zysku z inwestycji w relacje). Pierwszy z nich to poziom grupowy, w którym występują korzyści dla zbioru jednostek, drugi to poziom indywidualny. Zatem zarówno jednostki jak i grupy mogą być posiadaczami kapitału społecznego, ale tylko wtedy gdy jego zasoby są dla nich aktualnie dostępne. To właśnie zakres dostępu do sieci stanowi pośredni wskaźnik kapitału społecznego. Im większa liczba dróg dostępu do określonych zasobów, tym większe są rozmiary kapitału, jakie może spożytkować zarówno jednostka, jak i cała grupa. Idąc dalej tym

${ }^{41}$ T. Kaźmierczak, Kapitat społeczny a rozwój spoleczno-ekonomiczny - przegląd podejść [w:] Kapitał społeczny. Ekonomia społeczna, T. Kaźmierczak, M. Rymsza (red.), Instytut Spraw Publicznych, Warszawa 2007, s. 47.

Oczywiście również w polskiej literaturze przedmiotu, pojęcie kapitału społecznego zdobyło popularność wśród wielu badaczy. Do przykładowych opracowań, w których podejmowane są próby zdefiniowania tego pojęcia zaliczyć można m.in.: H. Januszek (red.), Kapitał społeczny we wspólnotach, Poznań 2005; M. Grewiński, S. Kamiński, Obywatelska polityka społeczna, Warszawa 2007; J. Czapiński, T. Panek (red.), Diagnoza społeczna 2007. Warunki i jakość życia Polaków. Raport, Warszawa 2007; M. Theiss, Krewni - znajomi - obywatele. Kapitat społeczny a lokalna polityka społeczna, Torun 2007; P. Sztompka, Socjologia. Analiza społeczeństwa, Kraków 2007. 
tokiem rozumowania, niektórzy autorzy wskazują na dwa typy zasobów, jakimi może dysponować jednostka: zasoby osobiste oraz zasoby społeczne. Zasoby osobiste to wszystko to, czym dysponuje, co posiada każdy człowiek (cechy fizyczne, wykształcenie, indywidualne umiejętności), natomiast zasoby społeczne to takie, które jednostka uzyskuje dzięki swoim koneksjom i relacjom z innymi i to właśnie ci inni stanowią źródło posiadanych przez nią indywidualnych już przewag. Oba rodzaje zasobów w konsekwencji mogą stanowić o wartości kapitału ludzkiego - i te pochodzące $\mathrm{z}$ relacji społecznych, i te stricte indywidualne ${ }^{42}$. Widoczny jest zatem dowód na to, że wartość kapitału ludzkiego zależy od czynników budujących kapitał społeczny.

Znając podstawowe definicje obu pojęć oraz ich główne elementy składowe, nawet jeśli występują pewne subtelne różnice między konkretnymi ujęciami, dużo łatwiej jest analizować możliwe do wystąpienia pomiędzy nimi współzależności. Jednym z zaproponowanych podejść do określenia owych zależności między dwoma rodzajami kapitału jest to, zaprezentowane przez K. Janca w opracowaniu pt.: „Zróżnicowanie przestrzenne kapitału ludzkiego i społecznego w Polsce". Autor, wykorzystując operacjonalizację kapitału ludzkiego, w podziale na dwie kategorie ( $w$ wymiarze ,instytucjonalnym" ${ }^{43}$ oraz w wymiarze „uczestnictwa”44), dokonuje analizy jego zróżnicowania, w zależności od poziomu wykształcenia ludności ogółem, poziomu wykształcenia radnych oraz obciążenia demograficznego. Wyniki jego analizy pokazują dodatnie współzależności między poziomem wykształcenia, a kapitałem społecznym „mającym swe źródła w nowoczesnych postawach" tj. np. aktywności stowarzyszeniowej, członkostwie w klubach sportowych. Zatem członkostwo i zaangażowanie $\mathrm{w}$ życie publiczne i społeczne w większym stopniu związane jest $\mathrm{z}$ wyższym poziomem wykształcenia. Natomiast ujemne związki zostały zidentyfikowane pomiędzy kapitałem ludzkim, a tymi elementami kapitału społecznego, które

${ }^{42}$ N. Lin, Social Capital: A theory of social structure and action, Cambridge University Press, Cambridge 2001, p. 21.

${ }^{43}$ W wymiarze ,instytucjonalnym” brane są pod uwagę tylko działania mogące świadczyć o poziomie kapitału społecznego bez uwzględnienia liczby osób w nich uczestniczących. Autor analizuje w tym wymiarze takie wskaźniki, jak: (1) samoorganizacja społeczeństwa - liczba fundacji i stowarzyszeń zarejestrowanych w systemie REGON na 10000 ludności, (2) liczba imprez zorganizowanych przez domy kultury, ośrodki kultury, świetlice, kluby na 1000 ludności; (3) liczba zespołów artystycznych i kół zainteresowań na 10000 ludności.

${ }^{44}$ Wymiar „uczestnictwa” świadczy o czynnym udziale w życiu społecznym, politycznym, kulturowym. Do tego wymiaru kapitału społecznego zostały zaklasyfikowane takie miary, jak: (1) członkowie klubów sportowych na 1000 ludności, (2) członkowie zespołów artystycznych na 1000 ludności, (3) członkowie kół zainteresowań na 1000 ludności, (4), zaangażowanie obywatelskie - frekwencja zbiorcza z: wyborów samorządowych, referendum unijnego, wyborów do Europarlamentu, wyborów parlamentarnych, wyborów prezydenckich. 
wiążą się z kultywowaniem tradycji ${ }^{45}$. Jest to oczywiście jedno z możliwych podejść do analizy związków między dwoma omawianymi kapitałami ${ }^{46}$. Warto jednak zwrócić również uwagę na zależności odwrotne, czyli w jaki sposób elementy kapitału społecznego wpływają na wartość czynników kapitału ludzkiego. Elementem podstawowym ${ }^{47}$ kapitału ludzkiego jest wiedza ucieleśniona w człowieku, to ona stanowi fundament jego rozwoju, a z kolei jej dyfuzja warunkuje rozwój gospodarczy, poprzez wzrost poziomu innowacyjności. Pytanie zatem, czy i w jaki sposób podstawowe elementy kapitału społecznego (sieci współpracy, zaufanie i normy) wpływają na proces zdobywania i dyfuzji wiedzy. Już J. Coleman zauważył, że do powstawania oraz reprodukcji kapitału ludzkiego, który stanowi podstawę konkurowania z innymi na rynku, niezbędny jest udział tego, co społeczne: relacji i związków, które składają się na kapitał społeczny $^{48}$. Konieczne okazało się wprowadzenie społecznego wymiaru do analizy sieci i zasobów, którymi mogą dysponować jednostki. Podstawą tych przekonań był fakt, że każda jednostka funkcjonuje w społeczeństwie, określonym otoczeniu i nie pozostaje wolna od jego wpływów. Otoczenie to, poprzez zbudowane w nim sieci, wypracowane relacje i związki wpływa na kształt każdej jednostki i determinuje warunki dla jej rozwoju. Istotą działania kapitału społecznego jest tworzenie warunków do nawiązywania współpracy i prowadzenia wymiany w społeczeństwie ${ }^{49}$. Sprowadza się to zatem do kreowania przyjaznego środowiska do tworzenia oraz dyfuzji wiedzy. Sprzyjać temu mają wypracowane relacje zaufania i wzajemności, stanowiące podstawę funkcjonowania $\mathrm{w}$ sieci. To właśnie zaufanie i udział $\mathrm{w}$ sieci powiązań eliminuje szereg różnorodnych barier w procesach tworzenia i rozprzestrzeniania się wiedzy, $\mathrm{tj}$.: brak dostępu (bądź utrudniony dostęp) do wiedzy specjalistycznej, długi czas dotarcia do informacji, brak skłonności do dzielenia się wiedzą (niwelowany głównie dzięki zaufaniu i normom wzajemności). Wszystkie procesy związane z zasobami wiedzy są zjawiskami złożonymi, zależnymi od wielu czynników

${ }^{45}$ Szerzej: K. Janc, Zróżnicowanie przestrzenne kapitału ludzkiego i społecznego w Polsce, Instytut Geografii i Rozwoju Regionalnego, Wrocław 2009, s. 93.

${ }^{46}$ Inne badania również dowodzą pozytywnego związku między wykształceniem a uczestnictwem w życiu społecznym i innymi zjawiskami, które wpływają na stan stosunków społecznych (przestępczością, zdrowiem), np. por. E. W. Glaeser, The Formation of Social Capital, OECD Conference Papers, 2001, http://www.sisreg.it/site/administrator/components/com jresearch/files /publications/ Glaeser_formation\%20social\%20capital_2001.pdf; B. Wolfe, R. Haveman, Accounting for Market and Non-market Gains of Education, OECD Conference Papers,2001, http://kmklim.republika.pl/ekonomia/resource/kapital.pdf.

${ }^{47}$ Pojawiającym się w każdej definicji tego pojęcia, bez względu na to, czy jest to ujęcie wąskie czy szerokie.

${ }^{48}$ Por. A. Portes, Social capital: Its origins and applications in modern sociology, Annual Reviews of Sociology, 24, 1998, s.4-5.

${ }^{49}$ I. Stavros, K. Nielsen (ed.), Economics and the Social Sciences: Boundaries, Interaction and Integration, Edward Edgar Publishing, 2007, s. 23. 
oraz od rodzaju samej wiedzy. Na przykład przy większym poziomie zaufania oraz podzielanej zasadzie wzajemności, występuje większa skłonność i prawdopodobieństwo do dzielenia się wiedzą utajoną, zaawansowaną i innowacyjną często cenniejszą z punktu widzenia rozwoju społeczno-gospodarczego ${ }^{50}$. Jednak niezależnie od rodzaju wiedzy uczenie się jest procesem zbiorowym, a w szerszej skali społecznym, który dokonuje się przez wzajemne oddziaływanie i współpracę pomiędzy różnymi podmiotami ${ }^{51}$. Dodatkowo należy zauważyć, że wiedza może istnieć nie tylko w umyśle człowieka jako jednostki, ale również w określonej zbiorowości. W kontekście wiedzy, zbiorowość może stanowić swojego rodzaju wartość dodaną, gdyż żaden członek określonej społeczności czy sieci, nie posiada całej wiedzy na dany temat, czy potrzebnej do rozwiązania danego problemu, lecz jako członek sieci (społeczności) jest w stanie wspólnie dany problem rozwiązać. Jako jednostka może być nie w pełni kompetentny, lecz jako „uczestnik” pewnej większej zbiorowości może być niezastapiony ${ }^{52}$.

Niektórzy autorzy, w kontekście zależności między czynnikami tworzącymi wartość kapitału społecznego i kapitału ludzkiego uwzględniają je już w samej definicji. Uznają ten pierwszy za wiedzę osadzoną w relacjach i stosunkach społecznych, której tworzenie, jak i przekazywanie wymaga właściwej kultury organizacyjnej, a zwłaszcza klimatu zaufania ${ }^{53}$. W takim ujęciu elementem tworzącym wartość zarówno jednego, jak i drugiego kapitału jest wiedza. Z kolei z drugiej strony większa jakość (zależna od wzajemnego zaufania i siły powiązań) i ilość kapitału społecznego sprzyja kreacji wiedzy, przede wszystkim dzięki wspomnianemu klimatowi zaufania. Kapitał ten posiada też wyjątkowo cenną wartość, ze względu na zmniejszanie kosztów poszukiwania informacji. Odpo-

${ }^{50}$ Pojęcie wiedzy utajonej (cichej, milczącej) wprowadził M. Polanyi, zwracając uwagę, że zawsze wiemy więcej, niż bylibyśmy w stanie wyrazić. Wiedza ta jest trudna bądź niemożliwa do skodyfikowania, trudno przekazać ją innym ludziom, ponieważ ciężko wyjaśnić samą istotę jej istnienia. Bardzo często jest to wiedza, którą posiadają tylko nieliczni pracownicy, wiedza specjalistyczna, fachowa, która jest zdecydowanie istotniejszym źródłem przewagi konkurencyjnej niż wiedza jawna. (M. Polanyi, Tacit Knowing: Its bearing on some problems of philosophy, Reviews of Modern Physics, Oct. 1962, 34 (4), s. 601-616). Z kolei podział na wiedzę podstawową, zaawansowaną i innowacyjną odwołuje się do klasyfikacji wiedzy identyfikowanej na gruncie organizacji. (Szerzej: Z. Przygodzki, Region wiedzy - wiedza i kapitat ludzki a rozwój regionu [w:] Region w gospodarce opartej na wiedzy. Kapitat ludzki - innowacje - korporacje transnarodowe, A. Nowakowska, Z. Przygodzki, M.E. Sokołowicz (red.), Wydawnictwo Difin, Warszawa 2011, s. 18).

${ }^{51}$ R. Domański, Regionalny poziom gospodarki uczqcej się, Czasopismo Geograficzne LXXI 2000, s. 3-4.

${ }^{52}$ Z. Przygodzki, Region wiedzy - wiedza i kapital ludzki a rozwój regionu [w:] Region w gospodarce opartej na wiedzy. Kapitat ludzki - innowacje - korporacje transnarodowe, A. Nowakowska, Z. Przygodzki, M.E. Sokołowicz (red.), Wydawnictwo Difin, Warszawa 2011, s. 23-24.

${ }_{53}$ M. Bugdol, Wartości organizacyjne. Szkice z teorii organizacji i zarządzania, Wydawnictwo Uniwersytetu Jagiellońskiego, Kraków 2006, s. 120-122. 
wiednio rozbudowana sieć kontaktów decyduje o tym, kto dowiaduje się pierwszy o nowinkach technologicznych, działaniach konkurencji, szansach rynkowych, itp. Ponadto funkcjonowanie w sieci stwarza łatwiejsze i większe możliwości wymiany pomiędzy jednostkami, posiadającymi większy poziom kapitału społecznego (sieci powiązań i współpracy), w tym również wymiany informacji i wiedzy.

Podsumowując powyższe rozważania należy stwierdzić, że elementy tworzące wartość kapitału społecznego i kapitału ludzkiego są względem siebie współzależne. Skłonność społeczeństwa do współpracy na rzecz dobra wspólnego, czy prezentowania postaw obywatelskich jest większa wśród osób lepiej wykształconych. $Z$ drugiej strony to wypracowanie często nieformalnych relacji i zaufania powoduje swobodniejszy przepływ informacji i wiedzy, tworząc tym samym odpowiednie środowisko dla kreacji innowacji.

\section{Znaczenie sieci współpracy i zaufania w przepływie informacji i dyfuzji wiedzy w regionie}

Sieci istniały w życiu człowieka od zawsze i w zasadzie były i są wszechobecne. Początkowo były najczęściej kojarzone z siecią opartą na infrastrukturze (siecią kolejową, drogowa, gazociagową, wodociągową), później z siecią komputerową. Współcześnie natomiast z sieciami społecznymi powstającymi np. wokół portali społecznościowych lub sieciami przedsiębiorstw, które wraz z infrastrukturą okołobiznesowa, instytucjami publicznymi, odpowiednimi zasobami kapitału ludzkiego, infrastrukturą techniczną i społeczną tworzą innowacyjne środowiska przedsiębiorczości ${ }^{54}$. Przyjmuje się, że podstaw teorii sieci można doszukiwać się w teorii grafów, jednak ze względu na wszechobecność sieci kategoria ta znalazła zastosowanie i stała się obszarem zainteresowań różnych dziedzin nauki. Pojęcie sieci i sieciowości na dobre zakorzeniło się we współczesnym języku zarówno naukowym, jak i publicystycznym. Wynikało to z konieczności znalezienia sposobu opisania nowej rzeczywistości, która powstała na skutek kompleksowych zmian technologicznych, ekonomicznych, społecznych oraz rozwojowi gospodarki globalnej. Spowodowało to zmiany w komunikacji, konkurencji, współpracy pomiędzy rożnego rodzaju podmiotami, poszczególnymi osobami, tworząc rzeczywistość, w której poszczególne obiekty są od siebie nawzajem zależne, tworząc tym samym rozległą, dyna-

${ }^{54}$ Szerzej: Z. Przygodzki, Innowacyjne środowiska przedsiębiorczości w kontekście procesów organizacji i regulacji w regionie [w:] Zrozumieć terytorium. Idea i praktyka, A. Nowakowska (red.), Wydawnictwo Uniwersytetu Łódzkiego, Łódź 2013, s. 105-116. 
miczną i często skomplikowaną strukturę o charakterze sieciowym ${ }^{55}$. Co więcej, w tym momencie trudno mówić np. jedynie o socjologicznych skutkach występowania sieci społecznych, gdyż są one tak samo istotne z punktu widzenia socjologów, jak i ekonomistów, decydując np. o warunkach procesów wymiany. Sieć jest zatem kategorią stosowaną w różnych kontekstach i przypisuje się jej wiele znaczeń. Jednak wśród tych różnych kontekstów wyraźnie widoczne są pewne podobieństwa, a biorąc pod uwagę coraz większe zainteresowanie tym zagadnieniem można przypuszczać, że współzależności pomiędzy poszczególnymi dziedzinami i dyscyplinami w tym zakresie będą coraz bardziej widoczne i odczuwalne. Dodatkowo w ciagu ostatnich lat dynamiczny wzrost znaczenia sieci potęgowany jest również przez rozwój technologii informacyjnych. Internet, jako powszechny środek komunikacji oraz platforma interakcji (biznesowych, społecznych), doprowadził do tego, że zarówno kooperacja, jak i różnego rodzaju procesy wymiany nabrały charakteru globalnego. Sam synonim Internetu - sieć globalna - wskazuje na to, że działania realizowane za jego pośrednictwem są sieciowe i o globalnym zasięgu ${ }^{56}$. M. Castells zwraca uwagę, że „każdy z tych dwóch procesów - tzn. oparty na organizacji sieciowej wzrost produktywności oraz oparta na sieciach globalizacja - jest napędzany przez szczególną branżę: technik informacyjnych, w coraz większym stopniu zorganizowaną wokół Intranetu, jako źródło nowych technologii i wyspecjalizowanej wiedzy o zarządzaniu dla całej gospodarki oraz branżę finansów jako siłę napędową tworzenia się elektronicznie powiązanego globalnego rynku finansowego, ostatecznego źródła inwestycji i tworzenia wartości dla całej gospodarki" ${ }^{57}$.

W literaturze sieć jest dosyć często przywoływanym hasłem w kontekście sposobu organizacji i koordynacji działalności gospodarczej, a w szczególności różnych wariantów współpracy. W ciągu ostatnich kilkudziesięciu lat poświęconych badaniom koncepcji sieci, ewoluowały podejścia do definiowania tego pojęcia oraz sposobu wyjaśniania za jego pomocą pewnych zachowań społeczno-gospodarczych. Podstawowy nurt w definiowaniu sieci wywodzi się z teorii kosztów transakcyjnych ${ }^{58}$. Teoria ta przewiduje, że gdy ani rynek, ani we-

${ }^{55}$ P. Stępka, K. Subda, Wykorzystanie analizy sieci spotecznych (SNA) do budowy organizacji opartej na wiedzy, e-mentor, nr 1 (28)/2009.

${ }^{56}$ K. Fuks, Sieci w nauce i gospodarce [w:] Sieci w gospodarce, M. Ciesielski (red.), Polskie Wydawnictwo Ekonomiczne, Warszawa 2013, s. 17.

${ }^{57}$ M. Castells, Społeczeństwo sieci, Wydawnictwo Naukowe PWN, Warszawa 2011, s. 182.

${ }^{58}$ M. Perry wskazuje jeszcze na dwie istotne perspektywy w definiowaniu pojęcia „sieci”: zmodyfikowaną perspektywę kosztów transakcyjnych oraz perspektywę zakorzenienia. Por. M. Perry, Small Firms and Networked Economies. Routledge Studies in Small Business, London1999, p. 4.

Za twórcę teorii kosztów transakcyjnych uznaje się R. H. Coase'a, a badania nad nią były kontynuowane przez jego ucznia O. E. Williamson'a. Podstawą tej teorii jest założenie, że zawieranie transakcji przez podmioty wiąże się z określonymi kosztami, nazwanymi przez twórcę teorii kosztami transakcji (koszty związane z poszukiwaniem dostawców, klientów, koszty negocjowa- 
wnętrzne hierarchie przedsiębiorstwa nie zapewniają satysfakcjonującego sposobu zarządzania transakcjami, możliwe jest rozwiązanie pośrednie. Zakłada się, że w odpowiedzi na ograniczenia, jakie występują w przypadku dwóch podstawowych form organizacji transakcji biznesowych, gdy zarówno transakcje rynkowe, jak i struktury hierarchiczne są obarczone zbyt wysokimi kosztami, wybór pada na powiązania hybrydowe - sporadyczne relacje, które są formą pośrednią, leżącą „gdzieś” pomiędzy rynkiem, a wewnętrzną hierarchią firmy ${ }^{59}$. Transakcje zawierane $\mathrm{w}$ ramach tych pośrednich form cechują się mniejszą niepewnością ekonomiczna, niż w przypadku tych realizowanych za pośrednictwem rynku, ale jednocześnie większą niż tych, dokonywanych w ramach wewnętrznej hierarchii. Określenie „sieci” pojawiło się jako jedna z propozycji nazwania i zdefiniowania zaobserwowanego fenomenu.

Z czasem pierwotna perspektywa analizy sieci, wyjaśniająca je jedynie przez pryzmat kosztów transakcyjnych, jako pośredniej formy koordynacji usytuowanej między dwoma wcześniej wyodrębnionymi (rynkiem i hierarchia), spotkała się z wyraźną krytyką zarówno ze strony ekonomistów jak i socjologów. Pojawiły się kolejne perspektywy spojrzenia na sieci, które wyrosły ze zmodyfikowanej perspektywy kosztów transakcyjnych oraz koncepcji zakorzenienia. W.W. Powell w swym artykule Neither Market Nor Hierarchy: Network Forms of Organization, mimo swych wcześniejszych założeń, stwierdził, że przyjęcie, iż sieci są formą pośrednią między hierarchią a rynkiem nie pozwala w zadowalającym stopniu wyjaśnić mechanizmów zachodzących w gospodarce. Uważał on, że sieci powinny być traktowane jako oddzielne formy koordynacji, a nie jak to było w przypadku teorii kosztów transakcyjnych, jako tymczasowe lub ubocz$n \mathrm{e}^{60}$. Zaproponowane przez niego porównanie poszczególnych form koordynacji działalności gospodarczej (rynku, hierarchii i sieci) według wybranych cech, stało się punktem wyjścia do definiowania i wskazywania specyficznych atrybutów sieci ${ }^{61}$. Podstawą sieci współpracy jest sytuacja, w której strony wymiany sa zależne, polegają na zasobach kontrolowanych przez drugą stronę i wszystkie strony czerpią profity z korzystania z tych zasobów. Forma ta częściej postrzegana jest jako nieformalna, elastyczna, czasem ograniczona do określonej grupy podobnych pod pewnymi względami podmiotów, wśród której buduje się zaufanie, lojalność. Podejście to nie spotkało się jednak z powszechną aprobata.

nia i podpisania umów, w dalszej kolejności koszty ich realizacji i kontroli). Szerzej: R.H. Coase, The Nature of the Firm, Economica New Series, Vol. 4, no. 16 (Nov., 1937), s. 386-405.

${ }^{59}$ O. E. Williamson, The Economic Institutions of Capitalism, The Free Press, New York 1987, s. 16; B. Thorelli, Networks: Between Markets and Hierarchies, Strategic Management Journal, Vol. 7 (1986), s. 37-51.

${ }^{60}$ Zob. W. W. Powell, Neither Market Nor Hierarchy: Network Forms of Organization, Research in Organizational Behavior, Vol. 12, 1990, p. 295-336.

${ }^{61}$ W. W. Powell, Neither Market Nor Hierarchy: Network Forms of Organization, Research in Organizational Behavior, Vol. 12, 1990, s. 299. 
Wyraźny sprzeciw podnosili w tym zakresie przedstawiciele tzw. teorii zakorzenienia (embeddedness) ${ }^{62}$ twierdząc, że wszystkie formy wymiany zawierają pewne cechy i elementy rynków, sieci oraz hierarchii i są osadzone w relacjach społecznych $^{63}$.

To właśnie do kategorii relacji i wzajemnych powiązań odnoszą się najczęściej spotykane, a zarazem najprostsze ujęcia sieci. Według tych ujęć, sieci stanowią zbiór relacji między aktorami (przedsiębiorstwami, przedsiębiorcami, organizacjami, instytucjami ponadnarodowymi, społecznością, itp.) - uczestnikami gry ekonomicznej ${ }^{64}$. Są one szczególnym rodzajem związków, formą wymiany cechującą się przede wszystkim luźnymi połączeniami, wzajemnością świadczeń, współzależnością aktorów i koordynacją ${ }^{65}$. Uczestnicy sieci nie inwestują jedynie $\mathrm{w}$ obiekty materialne, ale również $\mathrm{w}$ tworzenie odpowiadających im układów relacji ${ }^{66}$. Zarówno logikę funkcjonowania sieci, jak i jej znaczenie dla członków sieci najłatwiej przedstawić na przykładzie sieci przedsiębiorstw, jednak podmiotami sieci mogą być również banki, instytuty badawczorozwojowe, samorządy gospodarcze i terytorialne, administracja rządowa ${ }^{67}$. Dzięki licznym zaletom jakie się jej przypisuje, takim jak: naturalna elastyczność, łatwość dostosowania do bieżących wymogów otoczenia, możliwości zwiększania różnorodności i rozkładu ryzyka, zwiększania dostępu do technologii, możliwości zdobycia, transmisji, selekcji i kontroli informacji, sieci pojawiają się współcześnie we wszystkich dziedzinach życia gospodarczego i społecznego ${ }^{68}$. Według A. Jewtuchowicz, ,sieci są zbiorami wyselekcjonowanych związków z wybranymi partnerami, wpisującymi się w relacje rynkowe przedsiębiorstw. Są one efektem poszukiwania komplementarnych zasobów, a głównym motywem powstawania sieci jest synergia i dążenie do zmniejszenia niepewności działania. Powiązania w sieci są elastyczne i mogą tworzyć różne

${ }^{62}$ K. Polanyi wprowadził termin embeddedness, zwracając w swym dziele: The Great Transformation (1944) na konieczność zakorzenienia gospodarki w społeczeństwie.

${ }^{63}$ M. Granovetter, Economic Action and Social Structure: the Problem of Embeddedness, American Journal of Sociology 91 (3) 1985, s. 486.

${ }^{64}$ T. Stryjakiewicz, Sieciowa organizacja gospodarki a rozwój regionalny [w:] Wspótczesne problemy i koncepcje teoretyczne badań przestrzenno-ekonomicznych, T. Czyż, H. Rogacki (red.), Biuletyn KPZK PAN, Warszawa 2005, s. 41.

${ }^{65}$ F. Moulaert, F. Sekia, Territorial Innovation Models: A Critical Survey, Regional Studies, Vol. 37.3/2003, p. 291.

${ }^{66}$ T. Stryjakiewicz, Sieciowa organizacja gospodarki a rozwój regionalny [za:] E.J. Małecki, D.M. Tootle, Networks of Small Manufacturers in the USA: Creating the Embeddedness [w:] Interdependent and Uneven Development. Global-local perspectives, S. Conti, M. Taylor (red.), Ashgate 1997, s. 195-221.

${ }^{67}$ R. Domański, A. Marciniak, Sieciowe koncepcje gospodarki miast i regionów, Studia KPZK PAN, t. CXIII, Warszawa 2003, s. 5.

${ }^{68}$ A. Jewtuchowicz, Terytorium $i$ wspótczesne dylematy jego rozwoju, Wydawnictwo Uniwersytetu Łódzkiego, Łódź 2005, s. 31. 
kombinacje. Nie są one zdefiniowane a priori, ich powstanie wynika ze strategii partnerów"69. Relacje pomiędzy przedsiębiorstwami nie ograniczają się jedynie do relacji handlowych, czy kapitałowych. Dotyczą również transferu informacji, wiedzy, który w konsekwencji umożliwia i ułatwia wprowadzanie nowych technologii. Tym samym wszystkie przedsiębiorstwa, będące uczestnikami sieci i tego procesu, stają się bardziej konkurencyjne, natomiast region bardziej atrakcyjny dla kapitału zewnętrznego ${ }^{70}$. Sieć jest zatem efektywną formą organizacji, w której aktorzy postrzegają sukces bardziej jako wspólny wytwór własnego otoczenia, który wynika z relacji wzajemności, niż jako sukces gospodarczy wynikający $z$ wymiany opartej na regułach rynku. W rozwoju sieci duże znaczenie odgrywają relacje nieformalne oparte na zaufaniu i wzajemności (czynniki społeczno-kulturowe). Często ich występowanie utożsamiane jest $\mathrm{z}$ obecnością odpowiedniego poziomu różnych form bliskości. Zjawisko usieciowienia nie powinno być wyjaśniane głównie w ujęciu kosztów transakcji, ale powinno być raczej analizowane w kategoriach zachowań strategicznych, zdolności dostosowawczych, komplementarności technicznej czy czynników społecznych, takich jak: interpersonalne relacje, odpowiedzialność, zaufanie czy etyka współpracy ${ }^{71}$.

W ciagu ostatnich kilkunastu lat zaufanie stało się istotnym punktem zainteresowania nauk społecznych. Jest ono wskazywane jako podstawowy, konstytutywny element relacji międzyludzkich. Każda zbiorowość ludzka funkcjonuje na podstawie wzajemnego zaufania zbudowanego wśród jej członków i często to właśnie ten element decyduje o charakterze i sile danej grupy. To między innymi zaufanie umożliwia rozwój grup zorganizowanych wokół określonych idei ${ }^{72}$. Ekonomiści od dawna podkreślają jego nieocenioną rolę we wszystkich transakcjach wymiany. Jak stwierdza A. Smith człowiek może istnieć tylko w społeczności, a społeczność ta rozwija się i jest szczęśliwa w momencie, gdy wzajemna pomoc wynika z miłości, przyjaźni, szacunku i wdzięczności ${ }^{73}$. Zdaniem D. Golemana, „uśmiech, wzajemna życzliwość i zaufanie stanowią społeczną infrastrukturę, którą trzeba naprawiać, podobnie jak naprawiamy chodniki czy

${ }^{69}$ A. Jewtuchowicz, Rozwój, środowisko, sieci innowacyjne i lokalne systemy produkcyjne [w:] K. B. Matusiak, E. Stawasz, A. Jewtuchowicz (red.), Zewnętrzne determinanty rozwoju innowacyjnych firm, Wydawnictwo Uniwersytetu Łódzkiego, Łódź 2001, s. 82.

${ }^{0}$ A. Jewtuchowicz, Rozwój sieci i innowacyjnego środowiska przedsiębiorczości [w:] K. B. Matusiak, E. Stawasz, A. Jewtuchowicz (red.), Zewnętrzne determinanty rozwoju innowacyjnych firm, Wydawnictwo Uniwersytetu Łódzkiego, Łódź 2001, s. 234.

71 C. Freeman, Network of innovators: a synthesis of research issues, Reseach Policy, nr 20/1991, s. 499-514, [za:] J. Grzeszczak, Bieguny wzrostu a formy przestrzeni spolaryzowanej, Prace Geograficzne Instytutu Geografii i Przestrzennego Zagospodarowania PAN, nr 173, Wydawnictwo Continuo, Wrocław 1999, s. 53.

${ }_{72}$ P. Sztompka, Zaufanie. Fundament społeczeństwa, Wydawnictwo Znak, Kraków 2007, s. 245.

${ }^{73}$ A. Smith, Teoria uczuć moralnych, Wydawnictwo Naukowe PWN, Warszawa 1989, s. 125-126. 
oczyszczalnie ścieków" ${ }^{74}$. G.A Akerlof i R.J. Shiller stwierdzili, że zaufanie odgrywa główną rolę w makroekonomii, ponieważ implikuje pewne zachowania, które wykraczają poza racjonalne podejście do podejmowania decyzji. Uważają oni, że część decyzji podejmowana jest „na wyczucie”, determinowane przede wszystkim poziomem zaufania, podważając tym samym teorię standardowej ekonomii, według której decyduje się na podstawie przewidywanych efektów oraz prawdopodobieństwa ich wystapienia ${ }^{75}$. Nazwanie zaufania „ważnym smarem w systemie społecznym", którego brak może powodować opóźnienia w rozwoju gospodarczym, ma uświadomić jego rzeczywistą gospodarczą i społeczną wartość ${ }^{76}$. P. Sztompka nazywa je dodatkowo spoiwem w relacjach dlatego też jest tak istotne, z punktu widzenia współpracy zarówno w organizacji, jak i pomiędzy nimi ${ }^{77}$. Zaufanie jest odpowiedzialne za tworzenie „odpowiedniej atmosfery" dla przepływu informacji, kreacji wiedzy, kooperacji. Podejście to kontynuuje F. Fukuyama stwierdzając, że prawo, umowy i gospodarczy racjonalizm są niewystarczające dla zapewnienia dobrobytu społeczeństwa postindustrialnego. Konieczne jest dodatkowo występowanie pewnych wartości, opartych bardziej na zwyczajach - zaufania, niż chłodnych kalkulacjach ${ }^{78}$.

Zaufanie w potocznym rozumieniu kojarzone jest $\mathrm{z}$ życzliwością, uczciwością, otwartością, wiarygodnością, kompetencjami. Zaufanie do ludzi bądź rzeczy wiąże się z gotowością podjęcia ryzyka (wystawienia się na ryzyko), że mogą nas zawieść, połączoną z jednoczesnym oczekiwaniem, że stanie się inaczej $^{79}$. Jest to termin trudny do jednoznacznego zdefiniowania, a w literaturze przedmiotu proponowanych jest wiele jego określeń. Według jednych badaczy zaufanie jest wiarą w to, że osoba, z którą wchodzimy w interakcje cechuje się prawością charakteru, posiada właściwe kompetencje i kwalifikacje. $Z$ kolei inne ujęcie przedstawia zaufanie jako swego rodzaju wiarę w dobre intencje innych, dotrzymanie danego przez nich słowa, ogólnie - przewidywanie pewnych pozytywnych dla nas efektów działań innych osób ${ }^{80}$. Nie są to oczywiście wszystkie możliwe interpretacje zaufania, jednak można ogólnie przyjąć, że jest ono odzwierciedleniem, określeniem stanu naszych emocji, odczuć, rozumowania

${ }^{74}$ W. Idziak, Wymyślić wieś od nowa: wnioski tematyczne, Wydawnictwo Alta Press (Fundacja Wspomagania Wsi), Koszalin 2008, s. 151.

${ }^{75}$ Por. G. A. Akerlof, R. J. Shiller, Animal Spirits: How Human Psychology Drives the Economy, and Why It Matters for Global Capitalism, Princeton University Press, Princeton and Oxford 2009.

${ }^{76}$ K. J. Arrow, Granice organizacji, Wydawnictwo Naukowe PWN, Warszawa 1985, s. 15-20.

${ }^{77}$ P. Sztompka, Zaufanie. Fundament spoleczeństwa, Wydawnictwo Znak, Kraków 2007, s. 247.

${ }^{78}$ F. Fukuyama, Zaufanie. Kapitat spoteczny a droga do dobrobytu, Wydawnictwo Naukowe PWN, Warszawa 1997, s. 21.

79 B. Nooteboom, Trust: Forms, Foundations, Functions, Failures and Figures, Edaward Elegar Publishing, Northampton 2002, s. 45.

${ }^{80}$ Por. J. Penc, Zachowania organizacyjne w przedsiębiorstwie. Kreowanie twórczego nastawienia i aspiracji, Wydawnictwo Wolters Kluwer, Warszawa 2011, s. 326. 
i nastawienia wobec innych osób. Jest wynikiem procesu myślowego przeprowadzanego na podstawie docierających do nas informacji, wiedzy, sugestii, naszego doświadczenia, ale i pochodną pewnych wartościujących, ocenianych przez nas zdarzeń, sytuacji czy zachowań innych osób. Zaufanie jest zatem kategorią niezwykle złożoną, kształtowaną przez wiele różnorodnych czynników, które wpływają na nasze postrzeganie i w konsekwencji decydują o potencjalnej chęci obdarzenia kogoś tym zaufaniem ${ }^{81}$.

Zdaniem P. Sztompki, zaufanie to rodzaj zasobu, kapitału uruchamianego w nieustannym ,hazardzie" kontaktów z innymi ludźmi ${ }^{82}$. Dotyczy ono trzech sfer rzeczywistości społecznej, które stanowią jednocześnie jego aspekty:

- jest właściwością relacji wymiany między podmiotami (stanowiąc kluczowy element koncepcji kapitału społecznego);

- stanowi podstawę współpracy między nimi;

- jest normą kulturową.

Dokonując analizy typologicznej, ze względu na poziom zażyłości stosunków, można rozróżnić tzw. zaufanie „solidne”, którym obdarzają się osoby znane, pozostające w dobrych stosunkach oraz tzw. zaufanie „wątle”, między osobami znającymi się od niedawna, pomiędzy którymi nie wykształciły się zażyłe więzi. W sensie korzyści społecznych bardziej istotne okazuje się to drugie $^{83}$. Ze względu na podmiot, wobec którego wykształcane jest zaufanie można wyróżnić zaufanie poziome, wobec indywidualnych osób, o charakterze bardziej moralnym, osadzone w kategoriach norm kulturowych oraz zaufanie pionowe, wobec instytucji, władz publicznych, ogólnie rożnego rodzaju struktur instytucjonalnych, o charakterze bardziej racjonalnym ${ }^{84}$.

Oprócz szeregu funkcji o zabarwieniu społecznym ${ }^{85}$, jakie spełnia zaufanie, jego wymierną wartością pragmatyczną, z punktu widzenia ekonomii, jest obniżanie kosztów podejmowanych działań. Brak umiejętności stwarzania korzystnych warunków do obniżania kosztów transakcji (czyli brak umiejętności budowania społecznego zaufania), bywa wskazywany jako jedno z podstawowych

${ }^{81} \mathrm{~W}$. Walczak, Znaczenie zaufania w procesach zarzadzania kapitałem ludzkim - ujęcie wielowymiarowe, e-mentor, nr 5(47)/2012, (Dostęp: http://www.e-mentor.edu.pl/artykul/index/ numer/ 47/id/967).

${ }^{82}$ P. Sztompka, Socjologia. Analiza społeczeństwa, Wydawnictwo Znak, Kraków 2002.

${ }^{83}$ Uzupełnieniem tematu może być odwołanie do pojęcia „siły słabych więzi”, jako cechy współczesnego społeczeństwa, autorstwa $\mathrm{M}$. Granvoettera. Według niego nietrwałe formy stowarzyszania się i sieci powierzchownych znajomości, są dla ludzi bardziej użyteczne niż długotrwałe powiązania.

${ }^{84}$ Por. R. Inglehart, Trust, well-being and Democracy [w:] Democracy and Trust, M Warren (ed.), Cambridge University Press, New York and Cambridge 1999.

${ }^{85}$ Można wśród nich wyróżnić między innymi funkcję wspomagającą wykształcenie społeczeństwa obywatelskiego, funkcję stabilizującą i utrwalającą systemy demokratyczne, jak i funkcję tworzenia kapitału społecznego [za:] D. Walczak-Duraj, Socjologia dla ekonomistów, Polskie Wydawnictwo Ekonomiczne, Warszawa 2010, s. 83. 
źródeł stagnacji rozwoju społeczno-gospodarczego i niedorozwoju krajów Trzeciego Świata ${ }^{86}$. Poziom społecznego zaufania zależy od wielu różnorodnych czynników. Wśród autorów, ogniskujących swoją uwagę wokół tego zagadnienia, można wskazać kilka podejść do wyróżniania grup czynników, zmieniających poziom zaufania społecznego, z konkretnym wskazaniem spodziewanego kierunku zmian tego poziomu. D. Walczak-Duraj zwraca uwagę na sześć dających się wyróżnić grup ${ }^{87}$ :

1) czynniki statusowe - (wykształcenie, pozycja zawodowa, wielkość dochodów, itp.), występuje co do nich przypuszczenie, że im wyższy ich poziom, tym osoba jest bardziej skłonna do przejawiania społecznego zaufania;

2) czynniki relacyjne - (przynależność do różnego rodzaju organizacji, grup nieformalnych); im większa aktywność społeczna, tym spodziewany jest wyższy poziom zaufania;

3) czynniki środowiskowe - (opinie i więź ze środowiskiem zamieszkania, sąsiedztwo); silna więź ze środowiskiem lokalnym ma hipotetycznie sprzyjać budowaniu zaufania społecznego;

4) czynniki kulturowe - (postawa wobec tradycji, religijność, poziom tolerancji, akceptacji norm etycznych, itp.); im większy poziom akceptacji norm moralnych wyznaczających reguły postępowania, tym wyższy poziom zaufania;

5) czynniki psychospołeczne - (ogólna postawa wobec życia, poziomy lęku, frustracji, optymizm/pesymizm); im wyższy poziom negatywnych czynników tej grupy, czynników powodujących poczucie dyskomfortu psychicznego, tym wyższy poziom nieufności społecznej;

6) czynniki instytucjonalne - (postawa wobec instytucji formalnych i ich ocena, poziom zaangażowania/alienacji politycznej, postawy obywatelskie); negatywne opinie o instytucjach, powodując alienację polityczną, wpływają na wzrost nieufności względem innych ludzi.

Te najczęściej spotykane hipotezy, odnoszące się do czynników determinujących poziom zaufania społecznego potwierdzają złożoną specyfikę zjawiska i trudność jego jednoznacznego dookreślenia oraz stworzenia pewnych standardowych podejść do jego oceny i pomiaru. Dodatkowe wyzwanie stanowią ciagłe przemiany technologiczne, upowszechnianie nowoczesnych narzędzi informacyjno-komunikacyjnych, przyspieszenie ich rozwoju i permanentna zmienność, w obliczu których również zaufanie przybiera pewien „nowy”, właściwy sobie wymiar. We współczesnej gospodarce i społeczeństwie efektywność funkcjonowania podmiotów zależy między innymi od tego, w jakim stopniu i na ile są

${ }^{86}$ D. Walczak-Duraj, Socjologia dla ekonomistów, Polskie Wydawnictwo Ekonomiczne, Warszawa 2010, s. 83.

${ }^{87}$ D. Walczak-Duraj, Socjologia dla ekonomistów, Polskie Wydawnictwo Ekonomiczne, Warszawa 2010, s. 87. 
one skłonne do współpracy, kooperacji w zakresie wymiany informacji, dzielenia się wiedzą, ustawicznego kształcenia. Ta skłonność determinowana jest wypracowanymi relacjami, które z kolei zależą między innymi od określonego poziomu zaufania. To właśnie ono we wzajemnych relacjach zwiększa poczucie bezpieczeństwa oraz ułatwia otwartość informacyjną, co w konsekwencji znajduje swoje pozytywne odzwierciedlenie we wzroście przedsiębiorczości, innowacyjności oraz zdolności adaptacyjnej społeczeństwa oraz całej gospodarki.

Podsumowując, obecne przemiany społeczno-gospodarcze, zmierzające w kierunku kształtowania się społeczeństwa oraz gospodarki informacyjnej, determinują konieczność poszukiwania optymalnych sposobów tworzenia zasobów wiedzy, ich wykorzystania, dzielenia się nią, jak i pozyskiwania, transponowania i kontrolowania informacji. W modelu rozwoju opartego na wiedzy, optymalną formę organizacji życia społeczno-gospodarczego stanowią powiązania sieciowe. To one dzięki właściwej im specyfice, elastyczności dają możliwość dostosowywania się do zmiennych warunków zewnętrznych, sprzyjają innowacyjności oraz ułatwiają tworzenie i dyfuzję wiedzy. Sieć, jak pisze J. Naisbitt, to rozmawiający ze sobą ludzie, dzielący się pomysłami, wymieniający poglądami, informacjami i zasobami ${ }^{88}$. Dlatego właśnie umożliwiają szybki przepływ informacji, sprawniejsze nabywanie wiedzy i korzystanie z jej wyspecjalizowanych form, niedostępnych bezpośrednio na rynku. To właśnie sieć obniża koszty związane z jej pozyskaniem i przyspiesza procesy jej wdrażania. Stanowi instrument grupowego, a tym samym łatwiejszego uczenia się ${ }^{89} . Z$ kolei w samej sieci, podstawowe znaczenie odgrywają relacje (ugruntowane zaufaniem) występujące w postaci powiązań, opartych na zasadzie wzajemności. Owe zaufanie jest kategorią, która posiada wymierną wartość ekonomiczną. Jego brak powoduje rozpad społecznych związków, izolację społeczną, wyzwala negatywny stosunek do porządku prawnego. Deficyt zasobu jakim jest zaufanie pogłębia niepewność gospodarowania, kooperacji, współpracy, ponieważ oznacza, że nie można oczekiwać od partnera korzystnych i stosunkowo przewidywalnych oraz racjonalnych zachowań ${ }^{90}$.

${ }^{88}$ J. Naisbitt, Megatrendy: dziesięć nowych kierunków zmieniajacych nasze życie, Wydawnictwo Zysk i Spółka, Poznań 1997, s. 235.

${ }^{89}$ S. Korenik, Gospodarka oparta na wiedzy w skali regionu [w:] Gospodarka przestrzenna X, Z. Przybyła (red.), Wydawnictwo Akademii Ekonomicznej we Wrocławiu, Wrocław 2007, s. 177.

90 Szerzej: A. Matysiak, Wplyw kapitału społecznego na mechanizm rynkowy, Ekonomista, nr $4 / 2000$. 


\section{Narzędzia ICT w procesie budowania relacji społecznych i dyfuzji wiedzy (inwestycji w kapitał ludzki)}

W ciagu ostatnich kilku dziesięcioleci jesteśmy świadkami powstawania, a właściwie definiowania nowych procesów kształtujących rozwój świata, tzw. megatrendów rozwojowych, które w istotny sposób determinują zmiany zachodzące zarówno w gospodarce światowej, jak i sposobie funkcjonowania społeczeństwa. J. Naisbitt wskazuje na istnienie dziesięciu dających się wyróżnić megatrendów ${ }^{91}$ :

- kształtowanie się społeczeństwa informacyjnego;

- wzrost znaczenia nowoczesnych technologii;

- powstawanie gospodarki globalnej;

- wzrost znaczenia długofalowego planowania strategicznego;

- decentralizacja i znaczenie inicjatyw oddolnych;

- zmiany w kierunku demokracji uczestniczącej;

- rezygnacja z pomocy instytucjonalnej i zmiany w kierunku niezależności;

- wzrost znaczenia powiązań sieciowych;

- przesunięcie działalności gospodarczej z północy na południe;

- zmiany w kierunku społeczeństwa wielokrotnego wyboru.

Można stwierdzić, że wszystkie z nich zawierają się w ramach zmian, wynikających z rozwoju cywilizacji informacyjnej, opartej na wiedzy, informacji i rozwoju nowoczesnych technologii informacyjno-komunikacyjnych. Jednym $\mathrm{z}$ „filarów” owej cywilizacji, który generuje najwięcej, najbardziej odczuwalnych zmian w funkcjonowaniu społeczeństwa i gospodarki są narzędzia informacyjno-komunikacyjne. Korzenie współczesnych, zaawansowanych technologii informacyjnych i komunikacyjnych (ICT) wyrastają ze skonstruowanego w drugiej połowie XIX wieku przez Samuela F.B. Morse'a telegrafu. To on, poprzez wykorzystanie elektryczności w służbie komunikacji, na nowo zdefiniował informację. Przekształcił ją w towar, „rzecz”, którą można kupić i sprzedać, niezależnie od jej użyteczności czy znaczenia",92. Morse zapowiadał, że dzięki jego wynalazkowi „wszyscy staną się mieszkańcami jednej okolicy”"93. Termin ,technologie informacyjno-komunikacyjne" (Information and Communication Technologies - ICT) jest przywoływany w literaturze w kilku znaczeniach. Przez jednych badaczy jest on rozumiany wąsko, jako ogólna kategoria

${ }^{91}$ J. Naisbitt, Megatrendy: dziesięć nowych kierunków zmieniajacych nasze życie, Wydawnictwo Zysk i S-ka, Poznań 1997, s. 18-19.

${ }_{92}^{2}$ N. Postman, Zabawić się na śmierć. Dyskurs publiczny w epoce show-businessu, przeł. L. Niedzielski, Wydawnictwo Muza SA., Warszawa 2002, s. 103.

${ }^{93} \mathrm{Za}$ : N. Postman, Zabawić się na śmierć. Dyskurs publiczny w epoce show-businessu, przeł. L. Niedzielski, Wydawnictwo Muza SA., Warszawa 2002, s. 102. 
zbiorcza dla wszystkich środków przekazu, których wspólne wyznaczniki to przetwarzanie informacji w sposób cyfrowy oraz bazowanie na technologii mikroprocesowej. W tym ujęciu digitalizacja uznawana jest za podstawowy aspekt $\mathrm{ICT}^{94}$. Inni przedstawiciele świata nauki pojęcie to używają w kontekście szerszym, niż tylko odnoszącym się do technologii cyfrowych, zawierając również w nim wszystkie (także analogowe) technologie związane z procesem przetwarzania oraz dystrybucji informacji ${ }^{95}$. Zdaniem M. Sakowicza technologie te stanowią element „nowej infrastruktury”, przez którą rozumie on „różne rozwiązania organizacyjno-techniczne, służące do gromadzenia, przetwarzania i transmisji danych w postaci tekstu, dźwięku, obrazów zapisanych w formie cyfrowej. Nowa infrastruktura odnosi się do nowoczesnych narzędzi technicznych, obejmujących komputery, urządzenia peryferyjne, sieci (np. Internet) oraz organizacyjno-zarządczych, włącznie ze specjalistycznym oprogramowaniem (elektroniczny obieg dokumentów, system informacji przestrzennej), telepracą oraz organizacjami wirtualnymi”" ${ }^{\circ}$. W całej złożoności owej „nowej infrastruktury” fenomenem okazał się Internet. Nie sposób wymienić wszystkich nowych możliwości i zagrożeń, jakie niesie za sobą jego upowszechnienie, jednak z punktu widzenia inwestycji w kapitał ludzki istotne mogą okazać się zmiany generowane w dwóch obszarach: przepływu informacji i dyfuzji wiedzy oraz budowaniu relacji społecznych. To, że włączenie się do globalnej sieci umożliwia szybkie dotarcie do informacji, ich przesłanie czy wymianę jest kwestią bezsprzeczną. Nieco rzadziej jednak zwraca się uwagę, że Internet w znaczący sposób modyfikuje również „,czynnik”, stanowiący swego rodzaju podłoże dla przepływu informacji, wiedzy i ogólnego rozwoju kapitału ludzkiego - relacje społeczne. To właśnie relacje i umiejętność ich wypracowania umożliwiają porozumienie i współpracę pomiędzy podmiotami, są źródłem kreatywności, innowacyjności, przedsiębiorczości i ogólnie rozumianej aktywności. Inwestowanie w budowanie relacji stanowi ważny element $\mathrm{w}$ rozwoju zasobów intelektualnych.

Powstaje pytanie: jaki może być udział technologii informacyjno-komunikacyjnych w kształtowaniu relacji społecznych? Wśród badaczy zajmujących się tą tematyką nie ma zgody co do siły, jak i charakteru tego wpływu. Dla przykładu, w literaturze przedmiotu można znaleźć zarówno wyniki badań pokazujące, że korzystanie z Internetu przekłada się na słabsze więzi z bliskimi

${ }^{94}$ Por. D. McQuail, Teoria komunikowania masowego, Wydawnictwo Naukowe PWN, Warszawa 2007, s. 150-151; L. Porębski, Elektroniczne oblicze polityki. Demokracja, państwo, instytucje polityczne $w$ okresie rewolucji informacyjnej, Uczelniane Wydawnictwa NaukowoDydaktyczne Akademii Górniczo-Hutniczej, Kraków 2004, s. 12.

${ }_{95}$ M. Lister, J. Dovey, S. Giddings, I. Grant, K. Kelly, Nowe media: wprowadzenie, Wydawnictwo Uniwersytetu Jagiellońskiego, Kraków 2009, s. 634.

${ }^{96}$ M. Sakowicz, Modernizacja samorzqdu terytorialnego w procesie integracji Polski z Uniq Europejskq, Szkoła Główna Handlowa w Warszawie, Warszawa 2007, s. 142. 
i poczucie samotności ${ }^{97}$. Z czasem zostały one uznane za paradoks, jednak upowszechniły przekonanie o tym, że przestrzeń wirtualna jest przestrzenią konkurencyjną wobec fizycznej i poruszanie się w niej oddala ludzi, zamiast ich do siebie przybliżać. Późniejsze badania ${ }^{98}$ wyraźnie pokazały, że pierwotnie zaproponowane oraz zbyt szybko i szeroko uogólnione zależności, wcale nie są takie proste i jednoznaczne. Uznano, że są one zdeterminowane kontekstem, cechami psychicznymi użytkowników, sposobem i celem korzystania z sieci. Upowszechnienie technologii informacyjno-komunikacyjnych spowodowało, że mamy do czynienia $\mathrm{z}$ zacieraniem się granic między światem rzeczywistym a wirtualnym. Kontakty rzeczywiste, fizyczne w łatwy sposób mogą zamienić się w wirtualne i na odwrót. Sytuacja ta wymusiła redefinicję takich podstawowych pojęć jak: społeczność, więź i wiele innych, ponieważ Internet zaczął być postrzegany jako „nowy świat”, bogaty w społeczne powiązania i interakcje budowane przez „,nowe pokolenie" ${ }^{\text {99 }}$ uzależnione od nowoczesnych technologii ${ }^{100}$.

Wśród wielu badaczy wizje przyszłości, determinowane rozwojem technologii informacyjno-komunikacyjnych, były i nadal są często zupełnie odmienne. Najwięcej spekulacji na ten temat pojawiało się w latach 90. XX wieku, kiedy część krajów nadal była jeszcze przed „rewolucją technologiczną”, wejściem w erę cyfrową, część zaś mogła już mówić o pewnych zaobserwowanych efektach jej przebiegu. Jednym z przedstawicieli optymistycznej wizji procesów komunikacyjnych przyszłości (przepływu informacji i wiedzy) jest Nicholas Negroponte. Tłumaczył on zasady ery cyfrowej łatwym rozróżnieniem pomiędzy atomami i bitami. Rozprzestrzenianie się oraz wymiana atomów, w związku $\mathrm{z}$ ich materialną trójwymiarową formą, związana jest $\mathrm{z}$ tradycyjnymi ograniczeniami czasu i przestrzeni. Z kolei transfer bitów jest praktycznie natychmiastowy i pozbawiony ograniczeń przestrzennych. Jego zdaniem największą zaletą jest to, że informacja i wiedza w takiej formie są powszechnie dostępne. Negroponte

${ }^{97}$ R. Kraut, M. Patterson, V. Lundmark, S. Kiesler, T. Mukopadhyay, W. Scherlis, Internet Paradox. A Social Technology That Reduces Social Involvement and Psychological Well-Being ? American Psychologist, 53, pp. 1017-1031 (http://www.cs.cmu.edu/ kiesler/publications/1998pdfs/ 1998Kraut-InternetParadox.pdf) .

${ }^{98}$ Por. R. Kraut, S. Kiesler, B. Boneva, J. Cummings, V. Helgeson, A. Crawford, Internet Paradox Revisited, Journal of Social Issues, Vol. 58, no. 1, 2002, pp. 49-74 (http://onlinelibrary.wiley.com/ doi/10.1111/1540-4560.00248/pdf).

${ }^{99}$ Pokolenie to określane jest mianem ,,pokolenia Y" (Generation Y), ,pokolenia sieci” (Net Generation), „cyfrowego narodu” (Digital Nation), czy też od niedawna jako ostatni, ,najnowszy” typ mianem ,pokolenia Z”. Wśród twórców tych pojęć występują różnice co do jednoznacznego wskazania momentu ich narodzin. (Por. D. Lombard, Globalna wioska cyfrowa, MT Biznes, Warszawa 2009, s. 113).

${ }^{100}$ A. Borcuch, Cyfrowe spoleczeństwo w elektronicznej gospodarce, Wydawnictwo CeDeWu, Warszawa 2010, s. 96-98. 
przepowiadał, że ograniczenia czasu i przestrzeni zostaną obrócone wniwecz, a „cała cyfrowa planeta stanie się mała jak główka od szpilki”" ${ }^{101}$.

Optymistyczne podejście prezentuje również Bill Gates. Śmiało stwierdza on, że sieć pozwala włączyć się do społeczności z drugiej strony globu i jednocześnie daje możliwość wzmacniania więzi na „własnym podwórku”. „(..) Przyszło nam żyć we wspaniałych czasach. Początek ery informacji daje nam największą w historii świata szansę zakładania nowych firm, dokonywania nowych odkryć w dziedzinie medycyny i innych nauk, dla poprawienia jakości naszego życia. (...) Daje szansę na zrozumienie tego, co dzieje się wokół nas i na utrzymanie ciagłego kontaktu z rodziną i przyjaciółmi bez względu na to, gdzie się znajdują" ${ }^{02}$. Jego zdaniem sieciowy styl życia pozwala odrzucić wiele ograniczeń, które istniały już i tak wystarczająco długo. Swoje spostrzeżenia o poszerzaniu sfery wolności potwierdza on wzrostem możliwości wyboru w sferze konsumpcji. Nigdy wcześniej bowiem konsumenci nie mieli dostępu do tak szerokiego rynku dóbr, ale i informacji oraz wiedzy jak teraz, kiedy funkcjonują w sieci ${ }^{103}$. Od momentu pojawienia się Internetu drugiej generacji (tzw. Web 2.0) nastała nowa era, w której to użytkownicy decydują o jego wartości. Internet, oprócz narzędzia traktowanego głównie jako źródło danych i informacji, umożliwiającego budowanie wirtualnych społeczności oraz medium komunikacji, stał się dodatkowo przestrzenią, w której każdy podłączony może zamieścić swoje zasoby i jednocześnie korzystać z zasobów innych. Tim O’Reilly nazywa Web 2.0, w odróżnieniu od Internetu pierwszej generacji, którego cechowała hierarchia, fachowa kontrola i bierni użytkownicy, architekturą uczestnictwa, stanowiącą próbę uspołecznienia $\operatorname{sieci}^{104}$. Oczywiście słychać również głosy krytyki wobec takiego podejścia. Dla A. Kenna oznacza ono nic innego jak kolektywną ignorancję i kradzież, motłoch sieciowy oraz karykaturę demo$\operatorname{kracji}^{105}$

Inny głos przestrogi przed konsekwencjami związanymi z niekontrolowanym rozwojem ICT podnosi N. Postman. Przestrzega on przed potopem informacji, który jego zdaniem grozi nam w momencie, kiedy nie zostaną wypracowane skuteczne mechanizmy, pozwalające oddzielić z morza informacji te istot-

${ }^{101}$ N. Negroponte, Cyfrowe życie. Jak się odnaleźć w świecie komputerów, przeł. M. Łakomy, Wydawnictwo Książka i Wiedza, Warszawa 1997, s. 6-7.

102 B. Gates, Biznes szybki j@k myśl, przeł. B. Baryłko, I. Zygmunt-Fijałkowska, Wydawnictwo Prószyński i S-ka, Warszawa 1999, s. 334.

${ }^{103}$ B. Gates, Biznes szybki j@k myśl, przeł. B. Baryłko, I. Zygmunt-Fijałkowska, Wydawnictwo Prószyński i S-ka, Warszawa 1999, s. 137-139.

${ }^{104} \mathrm{~K}$. Krzysztofek, Wprowadzenie. WEBski świat: madrość tlumów sieciowych czy zbiorowe nieuctwo? [w:] A. Keen, Kult amatora. Jak internet niszczy kulture, Wydawnictwa Akademickie i Profesjonalne, Warszawa 2007, s. 12-14.

${ }^{105}$ Szerzej: A. Keen, Kult amatora. Jak internet niszczy kulture, Wydawnictwa Akademickie i Profesjonalne, Warszawa 2007. 
ne, od ,śmieci informacyjnych”. Jego zdaniem dużym błędem i zagrożeniem jest wiara technokratów, ,że informacja jest niekwestionowanym błogosławieństwem, a jej ciagłe i niekontrolowane wytwarzanie i rozpowszechnianie oferuje większą wolność, możliwości twórcze i spokój umysłu"106 oraz fakt, że zaczyna ona być traktowana już nie tylko jako środek, ale i sam cel ludzkiej twórczości $^{107}$. Z kolei S. Lem stwierdza, że jeśli zależy nam na społeczeństwie wzbogacanym osobniczymi możliwościami, powinniśmy zwrócić się do źródeł znacznie starszych aniżeli technologia informatyki, ponieważ jego zdaniem zarówno komputery, jak sieci są doskonałe, ale przede wszystkim w ich sprawnej bezmyślności ${ }^{108}$.

Jednak, jak już wcześniej wspomniano, niektórzy badacze w definiowaniu Internetu idą jeszcze dalej, postrzegając go już nie tylko jako multimedialny, globalny kanał komunikacji między ludźmi i instytucjami, ale również jako nowe społeczeństwo, istniejące $\mathrm{w}$ wirtualnej przestrzeni, w której zachodzą podstawowe procesy społeczne: „wirtualne spotkania”, dyskusje, biznesy, „randki”, itp. ${ }^{109}$. Jest postrzegany jako globalny zbiór różnorodnych, powiązanych ze sobą zasobów, z których wszystkie mogą być analizowane jako dobra wspólne. Szeroko rozumiany Internet składa się zatem z fizycznej infrastruktury sieciowej kabli, komputerów, przekaźników, protokołów (1); nieograniczonych zasobów informacyjnych (stron www, plików tekstowych, dźwiękowych, graficznych, itp.) dostępnych dzięki sieciowej infrastrukturze (2) oraz globalnego forum komunikacyjnego (3) ${ }^{110}$. To właśnie Internet w stopniu nieporównywalnym z żadną inną, współcześnie dostępną technologią komunikacyjną, wywiera ogromny i wszechstronny wpływ na życie społeczne jednostek i całych grup społecznych, nie tylko dając nowe możliwości w zakresie komunikacji, ale również jako miejsce budowania relacji społecznych. Człowiek, będąc istotą społeczną, z natury nastawiony jest na wymianę informacji, poglądów, uczuć, a współcześnie może odbywać się to również w świecie wirtualnym. Poprzez aktywność w sieci, między użytkownikami Internetu powstają więzi oparte początkowo na wspólnych zainteresowaniach, problemach, upodobaniach, które w konsekwencji stają się podstawą do zbudowania, wykształcenia tzw. e-społeczności. Tworzy się ,przestrzeń", gdzie ludzie czują się bezpieczni, potrzebni, zrozumiani, wysłuchani, zaakceptowani, do której często i chętnie wracają.

${ }^{106}$ N. Postman, Technopol. Triumf techniki nad kulturq, przeł. A. Tanalska-Dulęba, Państwowy Instytut Wydawniczy, Warszawa 1995, s. 91.

${ }^{107}$ N. Postman, Technopol. Triumf techniki nad kulturq, przeł. A. Tanalska-Dulęba, Państwowy Instytut Wydawniczy, Warszawa 1995, s. 78-80.

${ }_{108}$ S. Lem, Bomba megabitowa, Wydawnictwo Literackie, Kraków 1999, s. 210-211.

${ }_{109}$ Por. A. Nowak, K. Krejtz, Internet z perspektywy nauk społecznych [w:] Społeczna przestrzeń Internetu, D. Batorski, M. Marody, A. Nowak (red.), Warszawa 2006, s. 6-7.

${ }_{110} \mathrm{~J}$. Hofmokl, Definiowanie Internetu w kategoriach dóbr wspólnych [w:] Społeczna przestrzeń Internetu, D. Batorski, M. Marody, A. Nowak (red.), Warszawa 2006, s. 44. 
Technologie informacyjno-komunikacyjne w największym stopniu wpłynęły na kształt współczesnej rzeczywistości społeczno-gospodarczej, gdyż zmodyfikowały jeden z podstawowych procesów leżących u podstaw rozwoju każdej cywilizacji - proces komunikacji. Zmianie ulega tym samym sposób budowania relacji społecznych oraz przepływu informacji. Problem tworzenia się relacji społecznych w świecie wirtualnym należy rozpocząć od wskazania istoty samego komunikowania, a następnie analizy specyfiki tzw. komunikacji CMC. Sam termin „komunikowanie” wywodzi się z języka łacińskiego od czasownika communico, communicare, co $\mathrm{w}$ dosłownym thumaczeniu oznacza uczynić wspólnym, połączyć, udzielić komuś wiadomości, naradzać się oraz od rzeczownika communio - wspólność, poczucie łączności ${ }^{111}$. Pierwotne znaczenia tego pojęcia $\mathrm{z}$ czasem ewoluowały, obejmując dodatkowo kategorie transmisji i przekazu. Komunikowanie społeczne najczęściej definiowane jest jako proces porozumiewania się jednostek, grup czy instytucji, którego celem jest wymiana myśli, dzielenie się wiedza, informacjami czy ideami. Proces komunikowania odbywa się przy użyciu różnorodnych środków, na różnych poziomach i wywołuje określone skutki ${ }^{112}$. Jednak $\mathrm{w}$ ciągu lat, poświęconych badaniom procesu komunikowania, powstały setki definicji tego pojęcia ${ }^{113}$. Najczęściej przyjmuje się, że pierwotną sytuację komunikacyjną stanowi rozmowa twarzą w twarz dwóch osób ${ }^{114}$. Jednak takie podejście, w obliczu współczesnego postępu technologicznego, wydaje się zdecydowanie zbyt wąskie. Dzięki nowym środkom komunikacyjnym możemy obserwować budowanie nowych wspólnot, zwanych ogólnie społecznościami wirtualnymi, które w procesach komunikacji posługują się pewnymi własnymi kodami ${ }^{115}$. Na nazwanie komunikacji zapośredniczonej przez komputery, powstały konkretne określenia, takie jak komunikacja face-tomonitor, komunikacja face-to (via monitor)-face, czy też najpowszechniejsze: komunikacja CMC (computer mediated communication - komunikacja za po-

${ }^{111}$ Słownik łacińsko-polski, Warszawa 1973, s. 101 [za:] W. Gustowski, Komunikacja w mediach spolecznościowych, Wydawnictwo Novae Res, Gdynia 2012, s. 21.

${ }_{112}$ B. Dobek-Ostrowska, Podstawy komunikowania społecznego, Wrocław 2004, s. 13.

${ }^{113}$ Profesor Tomasz Goban-Klas w swej pracy pt. „Media i komunikowanie masowe” dokonuje obszernego przeglądu najbardziej charakterystycznych sposobów rozumienia tego pojęcia z punktu widzenia semantyki. Wśród badaczy najpowszechniejsze jest definiowanie komunikowania jako szeroko rozumianej transmisji. Por. T. Goban-Klas, Media i komunikowanie masowe: teorie $i$ analizy prasy, radia, telewizji i Internetu, Wydawnictwo Naukowe PWN, WarszawaKraków 1999, s. 42-43.

${ }^{114}$ W. Burszta, Internetowa polis w trzech krótkich odsłonach [w:] Ekran, mit, rzeczywistość, W. J. Burszta, Twój Styl, Warszawa 2003, s. 168.

${ }^{115}$ K. Krzysztofek, Społeczeństwo informacyjne a rozwój czlowieka [w:] Polska w drodze do globalnego społeczeństwa informacyjnego. Raport o rozwoju społecznym, W. Cellary (red.), Warszawa 2002, s. 101. 
średnictwem komputerów) ${ }^{116}$. Według B. Dobek-Ostrowskiej komunikacja $\mathrm{CMC}$ to forma komunikowania sieciowego, która opatrzona jest następującymi cechami ${ }^{117}$ :

- interpersonalny charakter (zasięg komunikowania ogranicza się do dwóch lub kilku jednostek);

- sieciowość (komunikowanie jest zapośredniczone przez urządzenia, które pracują w sieci);

- zerwanie jedności czasu i przestrzeni komunikowania;

- opóźnienie sprzężenia zwrotnego;

- zagrożenie częstym występowaniem szumów (mogące skutkować obniżeniem efektywności procesu komunikowania).

W. Gutowski dodaje do tej listy anonimowość oraz dialogiczność, czyli większą aktywność odbiorcy w procesie komunikacji, możliwość reagowania, głośnego komentowania przez niego konkretnych komunikatów, aż po sytuację, w której poprzez pewnego rodzaju dialog odbiorca staje się jednocześnie nadawcą komunikatu, mogącego stać się przedmiotem następnych komentarzy $^{118}$. Na czatach, forach dyskusyjnych, blogach, serwisach społecznościowych, serwisach aukcyjnych, internauci mogą zarówno prezentować swoje dzieła, uzyskiwać porady, skonfrontować różne opinie na dany temat, poszukiwać partnerów do prowadzenia biznesu, tworzyć grupy nacisku, wyrażać swoje emocje, modyfikować wiedzę na dany temat. Ogromną trudność sprawia wskazanie jednoznacznych efektów tego typu komunikacji dla więzi społecznych, głównie z tego względu, że zarówno zwolennicy jak i przeciwnicy nowoczesnych rozwiązań wskazują i traktują te same cechy owej komunikacji raz jako ograniczenia, raz jako nowe, pozytywne i korzystne możliwości dla ich rozwoju. Dla przykładu, jedną z cech komunikacji zapośredniczonej przez komputer jest brak (ograniczenie) poziomu niewerbalnego $\mathrm{w}$ komunikacji. Według niektórych uczonych brak tego typu informacji (o gestach, mimice, mowie ciała itp.) może skutkować zubożeniem nawiązywanych więzi, koniecznością poświęcenia większej ilości czasu na ich nawiązanie, mniejszym zrozumieniem i skupieniem się na „rozmówcy”, a tym samym tworzeniu jedynie słabych więzi. Z kolei zwolennicy, sięgając po ten sam argument braku (ograniczenia) komunikacji niewerbalnej, wskazują na jego zalety w budowaniu relacji społecznych, dzięki uwolnieniu się od schematycznych ocen przez pryzmat wyglądu czy płci. Większa

${ }^{116}$ P. Zawojski, Monitor między nami. O byciu razem i osobno w cyberprzestrzeni, [w:] Wiek ekranów: przestrzenie kultury widzenia, A. Gwóźdź, P. Zawojski (red.), Wydawnictwo Rabid, Kraków 2002 s. 428.

117 B. Dobek-Ostrowska, Komunikowanie polityczne i publiczne, Wydawnictwo Naukowe PWN, Warszawa 2007, s. 77.

${ }_{118}$ W. Gustowski, Komunikacja w mediach społecznościowych, Wydawnictwo Novae Res, Gdynia 2012, s.37-58. 
anonimowość często sprzyja otwartości, ograniczeniu lęku przed nawiązaniem znajomości ${ }^{119}$. Z kolei P. Wallace w swojej pracy „Psychologia Internetu” zwraca uwagę na jeszcze jedną bardzo istotną dla budowania relacji cechę Internetu (komunikacji CMC) - wzajemność zobowiązań. W swej pracy koncentruje się na zasadzie zobowiązań w cyberprzestrzeni, według tzw. spirali uczuć, działającej zgodnie ze schematem: „Ty lubisz mnie, ja lubię ciebie, ty lubisz mnie jeszcze bardziej" ${ }^{\prime 20}$. Co istotne, w tym przypadku obiektem wymiany jest sympatia, jednak równie dobrze może być to informacja, wiedza, dobra czy usługi wszystko co można wymienić w sieci. Zmieniając zatem przedmiot wymiany, funkcjonowanie $\mathrm{w}$ globalnej sieci odbywa się na zasadzie: ja podzielę się $\mathrm{z}$ tobą moją wiedzą, ty podzielisz się swoją, wtedy ja udostępnię Ci jeszcze więcej mojej wiedzy, w oczekiwaniu na otrzymanie równie większych zasobów twojej wiedzy. Taki mechanizm (wzajemności w relacjach) zdaniem Wallace powstaje dzięki możliwościom, jakie daje Internet i stanowi podstawę do tworzenia się wirtualnych społeczności.

Współcześnie fenomenem w kontekście tworzenia owych wirtualnych społeczności, jak i ogólnie procesów komunikacji, okazały się serwisy społecznościowe. W zasadzie trudno spotkać aktywnego użytkownika Intenetu, który nie kojarzyłby takich nazw jak Facebook, LinkedIn, Grono.net, Nasza-Klasa, MySpace. Serwisy społecznościowe, zdaniem D. Boyd i N. Ellison są to serwisy oparte na sieci, które pozwalają użytkownikom konstruować publiczny, lub półpubliczny profil wewnątrz powiązanego systemu (1); przedstawić listę użytkowników, z którymi jednostka ma powiązania (2); przejrzeć listę ich powiązań zarówno z innymi użytkownikami serwisu, jak i poza nim (3) ${ }^{121}$. Tak więc serwisy społecznościowe umożliwiają prezentowanie siebie i swoich powiązań społecznych oraz nawiązywanie i podtrzymywanie kontaktów. Z punktu widzenia znaczenia jednostki w ramach danego serwisu najistotniejsza wydaje się być rozległość sieci, czyli mówiąc inaczej liczba nawiązanych relacji. Mniej istotna okazuje się siła więzi łączących jednostki znajdujące się w sieci. Zdaniem tych autorów, tym co czyni wyjątkowość serwisów wcale nie jest fakt, że można spotkać tam i nawiązać kontakt z obcymi ludźmi, ale fakt, że można pokazać sieć swoich społecznych powiązań i poznać sieć powiązań innych. W konsekwencji może to zaowocować kontaktami, a dalej wymianą pewnych dóbr między jednostkami, które w innym razie nie miałyby na to szansy i interakcja między nimi nie zaistniałaby w ogóle. Dokonując analizy pojęcia „serwisy społecznościowe" pod kątem definicyjnym, punktem wyjścia jest jego odniesienie do

119 Szerzej: K. Barani, Rola więzi online w życiu człowieka [w:] Psychologiczne konteksty internetu, B. Szmigielska (red.), Wydawnictwo WAM, Kraków 2009, s. 106-113.

${ }^{120}$ P. Wallace, Psychologia internetu, Dom Wydawniczy Rebis, Poznań 2001, s. 191.

${ }^{121}$ D. Boyd, E. Nichole, Social Network Sites: Definition, History and Scholarship, Dostęp: http://jcmc.indiana.edu/vol13/issue1/boyd.ellison.html. 
kategorii społeczności - co jednak w niektórych obszarach może okazać się nieco mylące. Serwisy społecznościowe rozumiane są jako pewna określona zbiorowość, która podziela te same wartości, wspólne symbole stanowiące podstawę tożsamości grupy, przy jednoczesnym wytworzeniu podczas wspólnego działania pewnych obiektywnych zależności i stosunków między jej członka$\mathrm{mi}^{122}$. Kwestią sporna, w odniesieniu do klasycznego rozumienia społeczności, zbiorowości, jest brak potrzeby związku z terytorium. Tradycyjnie definiowana społeczność to kategoria ściśle związana z danym terytorium - zbiorowość ściśle ulokowana $\mathrm{w}$ określonej przestrzeni geograficznej, powiązana $\mathrm{z}$ jej politycznym, ekonomicznym, kulturowym aspektem ${ }^{123}$. Często jednak badacze Internetu również posługują się terminem „społeczności”, ale tak, jak np. B. Wellman odcinają się $\mathrm{w}$ proponowanych definicjach od jakichkolwiek konotacji przestrzennych, koncentrując się na relacjach międzyludzkich. Autor ten w jednym ze swoich artykułów o społecznościach w cyberprzestrzeni wyraźnie podkreśla: „Definiuję społeczności jako sieci więzi międzyludzkich, interpersonalnych, które zapewniają życie towarzyskie, wsparcie, informacje, poczucie przynależności i tożsamość społeczną. Nie ograniczam swojego myślenia o społecznościach, do sąsiedztwa i wiosek" ${ }^{\prime 124}$. Należy jednak podkreślić, że nie podważa on roli przestrzeni w kreowaniu poczucia wspólnotowości, jednak proponuje takie rozumienie wspólnotowości, które odwołuje się do dobrowolnie ustanawianych relacji między ludźmi, a nie jedynie „fatalizmu” miejsca urodzenia czy zamieszkania $^{125}$.

Pierwsze serwisy społecznościowe powstały na przełomie XX i XXI wieku. Jednym z pionierskich przedsięwzięć tego typu był serwis Sixdegrees.com ${ }^{126}$.

${ }^{122}$ Ł. Kapralska, O komunikacyjnych i integracyjnych funkcjach serwisów spotecznościowych [w:] com.unikowanie $w$ zmieniajacym się społeczeństwie, M. Niezgoda, M. Świątkiewicz-Mośna, A. Wagner (red.), Wydawnictwo NOMOS, Kraków 2010, s. 264.

${ }^{123}$ P. Starosta, Społeczność lokalna [w:] Encyklopedia Socjologii, t. IV, Z. Bokszański (red.), Oficyna Naukowa, Warszawa 2002, s. 97-107.

${ }^{124}$ B. Wellman, Physical Place and CyberPlace: The Rise of Personalized Networking, International Journal of Urban and Regional Research 25 (2001), Dostęp: http://homes.chass.utoronto.ca/ $\sim$ wellman/publications/index.html

${ }^{125}$ Ten sposób rozumienia społeczności lokalnych pojawił się już w latach 70 . XX wieku jako teoria społeczności bezlokalnych - o dość wąsko określonych celach, pomiędzy które członkowie dzielą swój czas, a które stanowią wynik postępującej specjalizacji w życiu społecznym. Twórcami tego podejścia są R. Pahl i E. Both. (Por. J. Turowski, Socjologia. Wielkie struktury spoteczne, Katolicki Uniwersytet Lubelski, Lublin 1994).

${ }^{126}$ Serwis ten działał w latach 1997-2001. Jego nazwa „sześć stopni” nie była przypadkowa. Odnosiła się bowiem do eksperymentu znanego psychologa Stanleya Milgrama, który używając pojęcia „sześciu stopni oddalenia” prowadził eksperymenty, mające udowodnić, że każdego człowieka na ziemi dzieli od innego, dowolnego człowieka, najwyżej sześć bliżej bądź dalej oddalonych od niego (w sensie kontaktów społecznych) osób. (S. Milgram, The Small-World Problem, Psychology Today, no 2, 1967, s. 60-67 [za:] Ł. Kapralska, O komunikacyjnych i integracyjnych funkcjach serwisów społecznościowych [w:] com.unikowanie w zmieniającym się społeczeństwie, 
Wśród pierwszych serwisów społecznościowych można znaleźć również takie nazwy jak: Friendster, MySpace, Orkut, Bebo, YouTube czy Facebook. W Polsce jednym z pierwszych tego typu serwisów był Grono.net, założony w 2004 roku. Przed erą Facebooka popularnością cieszył się serwis Nasza-Klasa. Bardzo prężnie rozwijały się również serwisy rekrutacyjno-zawodowe, takie jak GoldenLine.p ${ }^{127}$. Charakter serwisów społecznościowych jest bardzo zróżnicowany pod wieloma względami. Można wskazać chociażby kryterium dostępności, kryterium funkcji, wielkości, charakteru, przeznaczenia. Jedne są ogólnodostępne i każdy bez żadnych ograniczeń może stać się członkiem ich społeczności, z kolei inne w różny sposób ograniczają dostęp do swego grona, wprowadzając pewien rodzaj elitarności (np. poprzez konieczność uzyskania zaproszenia od innego członka ${ }^{128}$ ). Oferta jest różnorodna, od serwisów oferujących „wszystko dla wszystkich", po bardziej wyspecjalizowane, ograniczone w swym dostępie i tym samym ekskluzywne. Jednak bez względu na przyjętą typologię zawsze jest konieczne przyjęcie założenia, że prezentowane typy nie są wobec siebie rozłączne, gdyż ich funkcje i cele bardzo często się przenikają. Dla przykładu, jednym z zaproponowanych w literaturze podziałów ze względu na funkcje jakie pierwotnie miały pełnić serwisy społecznościowe jest ich rozgraniczenie na ${ }^{129}$ :

1. Serwisy biznesowe - nastawione na rekrutację, bądź też promowanie marki, w zależności od tego czy ich członkami są osoby indywidualne czy przedsiębiorstwa, organizacje;

2. Serwisy towarzyskie, rozrywkowe - których główną funkcją jest zapoznanie drugiej osoby, nawiązanie z nią bliższych, typowo towarzyskich, osobistych kontaktów, np. serwisy randkowe;

3. Serwisy służące autoprezentacji - mające na celu np. przedstawienie poza profilem własnej osoby również jej rozległej sieci znajomych;

4. Serwisy mające na celu rozwój zainteresowań (muzycznych, politycznych, itp.);

5. Serwisy poświęcone prezentacji twórczości ich użytkowników (serwisy zorientowane na użyteczną, poszukiwaną i pożądaną zawartość);

6. Serwisy poszukiwawcze, służące do znalezienia znanych i/lub nieznanych osób.

M. Niezgoda, M. Świątkiewicz-Mośna, A. Wagner (red.), Wydawnictwo NOMOS, Kraków 2010, s. 266.

${ }^{127}$ Będący odpowiednikiem amerykańskiego LinkedIn.com.

${ }^{128} \mathrm{Z}$ reguły nie ma ograniczeń co do liczby zaproszeń, jednak zdażają się wyjątki. Można zaliczyć do nich np. węgierski iWiW (International Who is Who), w którym czlonek dysponuje tylko jednym zaproszeniem do grona swoich znajomych.

${ }_{129}$ Przykładowa typologia opracowana na podstawie: Ł. Karpalska, O komunikacyjnych $i$ integracyjnych funkcjach serwisów społecznościowych [w:] com.unikowanie $w$ zmieniajacym sie społeczeństwie, M. Niezgoda, M. Świątkiewicz-Mośna, A. Wagner (red.), Wydawnictwo NOMOS, Kraków 2010, s. 267-269. 
Zasadniczo można stwierdzić, że wspólnym mianownikiem wszystkich wyżej zaproponowanych nierozłącznych typów jest odwołanie się do rozbudowania sieci znajomych i przyjaciół, nawiązania więzi. Inny przykład rozgraniczenia funkcji serwisów społecznościowych proponuje M. Moroz, zaliczając do nich możliwość nawiązania i podtrzymania kontaktu z innymi członkami serwisu, zaprezentowania danej osoby oraz różnorodnych treści przygotowanych przez nią, możliwość monitorowania aktywności pozostałych członków społeczności danego serwisu. ${ }^{130}$

Klasyk myśli cybersocjologicznej - Howard Rheingold określa wirtualne wspólnoty, jako społeczne zbiorowości, które formują się w sieci, kiedy wystarczająca liczba osób kontynuuje publiczne dyskusje na tyle długo i z takim emocjonalnym zaangażowaniem, aby w cyberprzestrzeni ukształtowały się sieci osobistych relacji ${ }^{131}$. Jednak zarówno ta definicja, jak i znaczenia zaproponowane przez innych badaczy mają w swej treści pewne niedoprecyzowania, co pokazuje, że ciężko wypracować jedną, ogólnie przyjętą definicję e-społeczności. Zdecydowanie łatwiej mówić o pewnych cechach tychże społeczności. Jest to grupa ludzi pomiędzy którą muszą zachodzić pewne interakcje. Mają one miejsce w środowisku wirtualnym, służą zaspokojeniu pewnych potrzeb, osiagnięciu jakiegoś celu i muszą trwać na tyle długo, aż pomiędzy jej członkami w wyniku licznych, mniej lub bardziej regularnych interakcji, wytworzą się pewne relacje. Dopiero występowanie tych relacji może doprowadzić do realizacji kolejnych działań, a rodzaj wypracowanych relacji decyduje o sposobie realizacji kolejnych działań, osadzonych cały czas w rzeczywistości wirtualnej, lub wychodzących już poza nią.

Przyrównując serwisy społecznościowe do wcześniej przedstawionych wirtualnych wspólnot, opisanych między innymi przez M. Smitha za pomocą tzw. „5A” (aprzestrzenność, asynchroniczność, acielesność, astygmatyczność, anonimowość), można znaleźć między nimi zarówno cechy wspólne jak i różnicujące. Jak zauważa $Ł$. Karpalska serwisy społecznościowe są w większym stopniu osadzone w rzeczywistej przestrzeni niż społeczności wirtualne, częściej też wykorzystują mieszane modele komunikowania - zarówno asynchroniczne, jak i synchroniczne. Zdjęcia często stanowią istotny element profilu użytkownika serwisu społecznościowego, co odbiega nieco od opisanej przez Smitha acielesności i astygmatyczności. Pytanie zatem, czy wirtualne wspólnoty i serwisy społecznościowe powinny być traktowane jako dwa odmienne typy „zbiorowości”

${ }^{130}$ M. Moroz, Źródła efektywności przekazu marketingowego w serwisach społecznościowych, e-mentor, nr 4 (36), 2010 [za:] M. Wawrzak-Chodaczek, Portale spolecznościowe jako miejsce komunikacji lokalnej w sieci globalnej, Kultura - Historia - Globalizacja, nr 13, 2013, s. 156. (Dostęp: http://www.khg.uni.wroc.pl/files/12_khg_13_wawrzak_t.pdf).

${ }^{131}$ H. Rheigold, The virtual community. Homesteading on the Electronic Frontier, Cambridge, Massachusetts, 2000, Wstęp [za:] W. Gustowski, Komunikacja w mediach społecznościowych, Wydawnictwo Novae Res, Gdynia 2012, s. 95. 
internetowych? Trudno wskazać jednoznaczną odpowiedź, jednak zdaniem autora serwisy społecznościowe można traktować jako swego rodzaju narzędzie do budowania wspólnot, lecz niekoniecznie jedynie wirtualnych. Stanowią jedno z narzędzi budowania, podtrzymania relacji międzyludzkich - o charakterze narzędzi informacyjno-komunikacyjnych, będąc platformą technologiczną do wymiany informacji, prezentacji własnej osoby, zainteresowań, twórczości. Oczywiście internauci sami decydują na ile zbudowane więzi będą silne, na ile będą chcieli podtrzymywać kontakty, czy też ich zaniechać i na ile mają być one rozległe. Bezsprzecznie są jednak odpowiedzią na zmiany zachowań, potrzeb i celów społecznych zapoczątkowane wraz z trzecim tysiącleciem. Skutki wykorzystania narzędzi informacyjno-komunikacyjnych w kontekście rozwoju zasobów ludzkich (inwestowania w kapitał ludzki) również mogą być różne, choć przeważają podejścia optymistyczne. Zdaniem wspomnianego już H. Rheingolda, pioniera badań nad społecznościami wirtualnymi, społeczeństwo masowe przyszłości będzie mobilne, twórcze i inteligentne dzięki „inteligencji roju”, gdzie pojedyncze ,egzemplarze gatunku” wykazywać będą dużo mniejszy zasób intelektualny niż cała grupa ${ }^{132}$. Co więcej, kontynuując ten nurt, spotkanie różnych „umysłów” w sieci może prowadzić do wykształcenia się kolektywnej inteligencji. Dzięki temu grupa może być aktywna i wykonywać pewne zadania jakby była inteligentnym, samomonitorującym się podmiotem, pracującym z jednym umysłem, a nie jedynie zbiorem niezależnych ,,agentów intelektualnych"133. W tych rozważaniach jeden ,wspólny umysł” można rozumieć i traktować również jako możliwość korzystania z pewnych wspólnych, ogólnodostępnych zasobów wiedzy, które mogą być wykorzystywane przez wiele różnych jednostek i mogą prowadzić do pewnych wspólnych (lecz jeśli jest taka potrzeba również indywidualnych) idei.

\section{Podsumowanie}

Wartości lokalnych zasobów kapitału ludzkiego i społecznego są ze sobą silnie skorelowane. Podstawową kategorią wiążącą te pojęcia jest człowiek i ucieleśniona $\mathrm{w}$ nim wiedza. Między innymi inwestycje $\mathrm{w}$ wiedzę stanowią o wartości kapitału ludzkiego. Jednak ich powodzenie i efektywność jest w du-

${ }^{132}$ H. Rheingold, Smart Mobs. The Next Social Revolution. Transfortning Cultures and Communities in the Age of Instant Access. Cambridge, Mass: Basic Books [za:] K. Krzysztofek, Spoleczeństwo $w$ dobie internetu: refleksyjne czy algorytmiczne? [w:] Re: internet - spoleczne aspekty medium, Polskie konteksty $i$ inspiracje, praca zbiorowa, Wydawnictwa Akademickie i Profesjonalne, Warszawa 2006, s. 24.

${ }^{133}$ K. Krzysztofek, Społeczeństwo $w$ dobie internetu: refleksyjne czy algorytmiczne? [w:] Re: internet - spoleczne aspekty medium, Polskie konteksty i inspiracje, praca zbiorowa, Wydawnictwa Akademickie i Profesjonalne, Warszawa 2006, s. 23. 
żej mierze zależne od środowiska i warunków w jakich zachodzą. Proces uczenia się, nabywania wiedzy jest procesem zbiorowym, a w szerszej skali społecznym. Dokonuje się przez wzajemne oddziaływanie i współpracę pomiędzy różnymi podmiotami. Poprzez interakcje pomiędzy indywidualnymi „właścicielami” wiedzy dochodzi do jej uwspólnienia i tym samym wzrostu wartości zasobów danej jednostki. Proces ten warunkowany jest pewnymi czynnikami typowo psychospołecznymi i kulturowymi. Wpływają na niego zarówno określone normy obowiązujące $\mathrm{w}$ danym środowisku, jak i wypracowane zaufanie pomiędzy jednostkami tworzącymi to środowisko. Występuje zatem wyraźne odwołanie do konstytutywnych kategorii kapitału społecznego. Współcześnie konieczne jest jednak uwzględnienie dodatkowego aspektu - człowiek nie funkcjonuje już jedynie w środowisku rzeczywistym, ale jego polem aktywności stało się również środowisko wirtualne. Bez względu na to, czy zjawisko to ocenia się jako pozytywne, czy też jako negatywne, Internet modyfikuje współczesne procesy komunikacji, przepływu wiedzy i informacji. $Z$ kolei znów, to właśnie komunikacja stanowi jeden z fundamentów budujących więzi i relacje społeczne, które obok zaufania, norm i sieci współpracy są podstawą kapitału społecznego. Wszystkie wyżej przedstawione współzależności analizowanych kategorii pozwalają wnioskować, że wykorzystanie nowoczesnych narzędzi w procesach komunikacji (w szczególności portali społecznościowych) może wzmacniać kapitał społeczny. Z kolei zaufanie, podzielane normy i wartości oraz sieci współpracy, tworząc środowisko dla wymiany i socjalizacji wiedzy, wpływają jednocześnie na wartość kapitału ludzkiego obecnego w regionie.

\section{Bibliografia}

Akerlof G. A., Shiller R. J., Animal Spirits: How Human Psychology Drives the Economy, and Why It Matters for Global Capitalism, Princeton University Press, Princeton and Oxford 2009.

Arrow K. J., Granice organizacji, Wydawnictwo Naukowe PWN, Warszawa 1985.

Barani K., Rola więzi online w życiu czlowieka [w:] Psychologiczne konteksty Internetu, B. Szmigielska (red.), Wydawnictwo WAM, Kraków 2009.

Becker G., Ekonomiczna teoria zachowań ludzkich, Wydawnictwo Naukowe PWN, Warszawa 1990.

Becker G.S., Human capital: A theoretical and empirical analysis with special reference to education, Columbia University Press, New York 1975; Borcuch A., Cyfrowe spoleczeństwo w elektronicznej gospodarce, Wydawnictwo CeDeWu, Warszawa 2010.

Bourdieu P., Wacquant J.D.L., Zaproszenie do socjologii refleksyjnej, Oficyna Naukowa, Warszawa 2001.

Boyd D., Nichole E., Social Network Sites: Definition, History and Scholarship, Dostęp: http://jcmc.indiana.edu/vol13/issue1/boyd.ellison.html. 
Bratnicki M., Strużyna J. (red.), Przedsiębiorczość i kapitat intelektualny, Wydawnictwo Uczelniane Akademii Ekonomicznej im. K. Adamieckiego w Katowicach, Katowice 2001.

Bugdol M., Wartości organizacyjne. Szkice z teorii organizacji i zarządzania, Wydawnictwo Uniwersytetu Jagiellońskiego, Kraków 2006.

Burszta W., Internetowa polis $w$ trzech krótkich odsłonach [w:] Ekran, mit, rzeczywistość, Burszta W. , Twój Styl, Warszawa 2003.

Castells M., Społeczeństwo sieci, Wydawnictwo Naukowe PWN, Warszawa 2011.

Chojnicki Z., Wiedza dla gospodarki w perspektywie OECD [w:] Gospodarka oparta na wiedzy - wyzwania dla Polski XXI wieku, Kukliński A. (red.), KBN, Warszawa 2001.

Cichy K., Malaga K., Kapitał ludzki w modelach teorii wzrostu gospodarczego, Polskie Towarzystwo Ekonomiczne, http://www.pte.pl/pliki/2/12/Kapital_ludzki_ujecie_modelowe.pdf

Coase R.H., The Nature of the Firm, Economica New Series, Vol. 4, no. 16 (Nov., 1937).

Coleman J.S., A rational choice perspective on economic sociology [in:] Handbook of Economic Sociology, Smelser N.J, Swedberg R. (ed.), Princeton University Press, Princeton 1994.

Coleman J.S., Foundations of Social Theory, MA: The Belknap Press, Cambridge 1990.

Czyżewski A. B., Góralczyk-Modzelewska M., Saganowska E., Wojciechowska M., Regionalne zróżnicowanie kapitału ludzkiego w Polsce, Z Prac Zakładu Badań Statystyczno-Ekonomicznych, zeszyt 277, Zakład Badań Statystyczno-Ekonomicznych GUS i PAN, Warszawa 2001.

Dobek-Ostrowska B., Komunikowanie polityczne i publiczne, Wydawnictwo Naukowe PWN, Warszawa 2007.

Dobek-Ostrowska B., Podstawy komunikowania spolecznego, Wrocław 2004.

Domański R., Regionalny poziom gospodarki uczqcej się, Czasopismo Geograficzne LXXI 2000.

Domański R., Kapitat ludzki i wzrost gospodarczy, Wydawnictwo Naukowe PWN, Warszawa 1992.

Domański R., Marciniak A., Sieciowe koncepcje gospodarki miast i regionów, Studia KPZK PAN, t. CXIII, Warszawa 2003.

Drucker P.F., The Age of Social Transformation, The Atlantic Monthly, November 1994 [za:] Kolarz M., Znaczenie wiedzy i kapitału intelektualnego we współczesnej gospodarce i organizacji [w:] Kapitat ludzki w dobie integracji i globalizacji, Kożusznik B. (red.), Wydawnictwo Uniwersytetu Śląskiego, Katowice 2005.

Freeman C., Network of innovators: a synthesis of research issues, Reseach Policy no. 20/1991 [za:] Grzeszczak J., Bieguny wzrostu a formy przestrzeni spolaryzowa$n e j$, Prace Geograficzne Instytutu Geografii i Przestrzennego Zagospodarowania PAN, nr 173, Wydawnictwo Continuo, Wrocław 1999.

Fuks K., Sieci w nauce i gospodarce [w:] Sieci w gospodarce, Ciesielski M. (red.), Polskie Wydawnictwo Ekonomiczne, Warszawa 2013.

Fukuyama F., Social capital and global economy, Foreign Affairs 1995, 74 (5).

Fukuyama F., Zaufanie. Kapitat społeczny a droga do dobrobytu, Wydawnictwo Naukowe PWN, Warszawa 1997.

Gates B., Biznes szybki j@k myśl, przeł. Baryłko B., Zygmunt-Fijałkowska I., Wydawnictwo Prószyński i S-ka, Warszawa 1999. 
Gittell R.J., Vidal A., Community organizing: building social capitalas a development strategy, Thousand Oaks, Sage 1998.

Glaeser E. W., The Formation of Social Capital, OECD Conference Papers, 2001, http://www.sisreg.it/site/administrator/components/com jresearch/files/publications/ Glaeser_formation\%20social\%20capital_2001.pdf; B. Wolfe i R. Haveman, Accounting for Market and Non-market Gains of Education, OECD Conference Papers,2001, http://kmklim.republika.pl/ekonomia/resource/kapital.pdf.

Goban-Klas T., Media i komunikowanie masowe: teorie $i$ analizy prasy, radia, telewizji i Internetu, Wydawnictwo Naukowe PWN, Warszawa-Kraków 1999.

Gospodarka oparta na wiedzy - stan, diagnoza i wnioski dla Polski, Instytut Zarządzania Wiedzą w Krakowie, Warszawa-Kraków 2002.

Granovetter M., Economic Action and Social Structure: the Problem of Embeddedness, American Journal of Sociology, 91 (3) 1985.

Grewiński M., Kamiński S., Obywatelska polityka społeczna, Warszawa 2007.

Grodzicki J., Rola kapitału ludzkiego w rozwoju gospodarki globalnej, Wydawnictwo Uniwersytetu Gdańskiego, Gdańsk 2003.

Gustowski W., Komunikacja w mediach społecznościowych, Wydawnictwo Novae Res, Gdynia 2012.

Hanifan L. J., The Rural School Community Center, Annals of the American Academy of Political and Social Science, no. 67, 1916.

Harrison L.E., Huntington S.P. (red.), Kultura ma znaczenie, Wydawnictwo Zysk i S-ka, Poznań 2003.

Hejduk I.K., Korczak J. (red.), Gospodarka oparta na wiedzy, Wydawnictwo Uczelniane Politechniki Koszalińskiej, Koszalin 2006.

Hofmokl J., Definiowanie Internetu w kategoriach dóbr wspólnych [w:] Społeczna przestrzeń Internetu, Batorski D., Marody M., Nowak A. (red.), Warszawa 2006.

Idziak W., Wymyślić wieś od nowa: wnioski tematyczne, Wydawnictwo Alta Press (Fundacja Wspomagania Wsi), Koszalin 2008.

Inglehart R., Trust, well-being and Democracy [in:] Democracy and Trust, M Warren (ed.), Cambridge University Press, New York and Cambridge 1999.

Janc K., Zróżnicowanie przestrzenne kapitału ludzkiego i społecznego w Polsce, Instytut Geografii i Rozwoju Regionalnego, Wrocław 2009.

Januszek H. (red.), Kapitał społeczny we wspólnotach, Poznań 2005.

Jarecki W., Koncepcja kapitału ludzkiego [w:] Kapitał ludzki w gospodarce, Kopycińska D. (red.), Polskie Towarzystwo Ekonomiczne, Szczecin 2003.

Jewtuchowicz A., Rozwój sieci i innowacyjnego środowiska przedsiębiorczości [w:] Zewnętrzne determinanty rozwoju innowacyjnych firm, Matusiak K. B., Stawasz E., Jewtuchowicz A. (red.), Wydawnictwo Uniwersytetu Łódzkiego, Łódź 2001.

Jewtuchowicz A., Rozwój, środowisko, sieci innowacyjne i lokalne systemy produkcyjne [w:] Zewnętrzne determinanty rozwoju innowacyjnych firm, Matusiak K. B., Stawasz E., Jewtuchowicz A. (red.), Wydawnictwo Uniwersytetu Łódzkiego, Łódź 2001.

Jewtuchowicz A., Terytorium i współczesne dylematy jego rozwoju, Wydawnictwo Uniwersytetu Łódzkiego, Łódź 2005. 
Kapralska Ł., O komunikacyjnych i integracyjnych funkcjach serwisów społecznościowych, [w:] com.unikowanie $w$ zmieniajacym się społeczeństwie, Niezgoda M., Świątkiewicz-Mośna M., Wagner A. (red.), Wydawnictwo NOMOS, Kraków 2010.

Kaźmierczak T., Kapitat społeczny a rozwój społeczno-ekonomiczny - przeglad podejść [w:] Kapitał społeczny. Ekonomia społeczna, Kaźmierczak T., Rymsza M. (red), Instytut Spraw Publicznych, Warszawa 2007.

Keen A., Kult amatora. Jak Internet niszczy kulturę, Wydawnictwa Akademickie i Profesjonalne, Warszawa 2007.

Kolarz M., Znaczenie wiedzy i kapitału intelektualnego we współczesnej gospodarce $i$ organizacji [w:] Kapitał ludzki $w$ dobie integracji i globalizacji, Kożusznik B. (red.), Wydawnictwo Uniwersytetu Śląskiego, Katowice 2005.

Kopycińska D., (red.), Konkurencyjność rynku pracy i jego podmiotów, Wydawnictwo Naukowe Katedry Mikroekonomii Uniwersytetu Szczecińskiego, Szczecin 2005.

Korenik S., Gospodarka oparta na wiedzy w skali regionu [w:] Gospodarka przestrzen$n a X$, Z. Przybyła (red.), Wydawnictwo Akademii Ekonomicznej we Wrocławiu, Wrocław 2007.

Kożusznik B. (red.), Kapitał ludzki w dobie integracji i globalizacji, Wydawnictwo Uniwersytetu Śląskiego, Katowice 2005.

Kraut R., Kiesler S., Boneva B., Cummings J., Helgeson V., Crawford A., Internet Paradox Revisited, Journal of Social Issues, Vol. 58, no. 1, 2002 (http://onlinelibrary.wiley.com/ doi/10.1111/1540-4560.00248/pdf)

Kraut R., Patterson M., Lundmark V., Kiesler S., Mukopadhyay T., Scherlis W., Internet Paradox. A Social Technology That Reduces Social Involvement and Psychological Well-Being ? American Psychologist. (http://www.cs.cmu.edu/ kiesler/ publications/1998pdfs/1998Kraut-InternetParadox.pdf)

Krzysztofek K., Społeczeństwo informacyjne a rozwój człowieka [w:] Polska w drodze do globalnego społeczeństwa informacyjnego. Raport o rozwoju społecznym, Cellary W. (red.), Warszawa 2002.

Krzysztofek K., Społeczeństwo $w$ dobie Internetu: refleksyjne czy algorytmiczne? [w:] Re: internet - spoleczne aspekty medium, Polskie konteksty i inspiracje, praca zbiorowa, Wydawnictwa Akademickie i Profesjonalne, Warszawa 2006.

Krzysztofek K., Wprowadzenie. WEBski świat: madrość tlumów sieciowych czy zbiorowe nieuctwo? [w:] Keen A., Kult amatora. Jak Internet niszczy kulturę, Wydawnictwa Akademickie i Profesjonalne, Warszawa 2007.

Kukliński A. (red.), Gospodarka Oparta na Wiedzy - wyzwania dla Polski XXI wieku, KBN, Warszawa 2001.

Kwiatkowski S., Sharif N. M., Intellectual Entrepreneurship and Courage to Act, Publishing House of Leon Kozminsky Academy of Entrepreneurship and Management, Warsaw 2005.

Lem S., Bomba megabitowa, Wydawnictwo Literackie, Kraków 1999.

Lin N., Social Capital: A theory of social structure and action, Cambridge University Press, Cambridge 2001.

Lister M., Dovey J., Giddings S., Grant I., Kelly K., Nowe media: wprowadzenie, Wydawnictwo Uniwersytetu Jagiellońskiego, Kraków 2009.

Lombard D., Globalna wioska cyfrowa, MT Biznes, Warszawa 2009. 
Loury G.C., A dynamic theory of racial income differences [w:] Wallace P.A., LaMond A.M. (eds.), Women, Minorities, and Employment Discrimination, MA: Heath, Lexington 1977.

Loury G.C., Intergenerational transfers and the distribution of earnings, Econometrica 1981, no. 49.

Markowska M., Zróżnicowanie europejskiej przestrzeni regionalnej w świetle koncepcji gospodarki opartej na wiedzy [w:] Gospodarka lokalna i regionalna w teorii i praktyce, Strahl D. ( red.), Prace Naukowe Akademii Ekonomicznej im. O. Langego we Wrocławiu, nr 1161, Wydawnictwo Akademii Ekonomicznej im. O. Langego we Wrocławiu, Wrocław 2007.

Matysiak A., Wpływ kapitału społecznego na mechanizm rynkowy, Ekonomista, nr 4/2000.

McQuail D., Teoria komunikowania masowego, Wydawnictwo Naukowe PWN, Warszawa 2007.

Mempel-Śnieżyk A., Kapitał ludzki i kapitał społeczny w gospodarce opartej na wiedzy [w:] Nowe paradygmaty gospodarki przestrzennej, Miszczak K., Przybyła Z. (red.), Biuletyn KPZK PAN, zeszyt 236, Warszawa 2008.

Michalczyk T., Musioł S., Kapitał ludzki i społeczny a rozwój społeczno-ekonomiczny w świetle nowej analizy instytucjonalnej [w:] Kapitały ludzkie i społeczne a konkurencyjność regionów, M. S. Szczepański, K. Bierwiaczonek, T. Nawrocki (red.), Wydawnictwo Uniwersytetu Śląskiego, Katowice 2008.

Milgram S., The Small-World Problem, Psychology Today, no. 2, 1967 [za:] Kapralska Ł., O komunikacyjnych i integracyjnych funkcjach serwisów społecznościowych [w:] com.unikowanie $w$ zmieniajacym się społeczeństwie, Niezgoda M., ŚwiątkiewiczMośna M., Wagner A. (red.), Wydawnictwo NOMOS, Kraków 2010.

Moroz M., Źródła efektywności przekazu marketingowego w serwisach społecznościowych, e-mentor, nr 4 (36), 2010 [za:] Wawrzak-Chodaczek M., Portale spotecznościowe jako miejsce komunikacji lokalnej w sieciglobalnej, Kultura - Historia - Globalizacja, nr 13, 2013. (Dostęp: http://www.khg.uni.wroc.pl/ files/12_khg_13_wawrzak_t.pdf).

Moulaert F., Sekia F., Territorial Innovation Models: A Critical Survey, Regional Studies, Vol. 37.3/2003.

Naisbitt J., Megatrendy: dziesięć nowych kierunków zmieniajacych nasze życie, Wydawnictwo Zysk i Spółka, Poznań 1997.

Negroponte N., Cyfrowe życie. Jak się odnaleźć w świecie komputerów, przeł. Łakomy M., Wydawnictwo Książka i Wiedza, Warszawa.

Nooteboom B., Trust: Forms, Foundations, Functions, Failures and Figures, Edaward Elegar Publishing, Northampton 2002.

Nowak A., Krejtz K., Internet z perspektywy nauk społecznych [w:] Spoleczna przestrzeń Internetu, Batorski D., Marody M., Nowak A. (red.), Warszawa 2006.

OECD, Knowledge management in the learning society. Education and skills. OECD 2000, Paris.

Onak-Szczepanik B., Budowa gospodarki opartej na wiedzy w Polsce w kontekście integracji z Uniq Europejska [w:] Konkurencyjność rynku pracy i jego podmiotów, Kopycińska D (red.), Wydawnictwo Naukowe Katedry Mikroekonomii Uniwersytetu Szczecińskiego, Szczecin 2005.

Penc J., Zachowania organizacyjne w przedsiębiorstwie. Kreowanie twórczego nastawienia i aspiracji, Wydawnictwo Wolters Kluwer, Warszawa 2011. 
Perry M., Small Firms and Networked Economies. Routledge Studies in Small Business, London 1999.

Polanyi M., Tacit Knowing: Its bearing on some problems of philosophy, Reviews of Modern Physics, Oct. 1962, 34 (4).

Porębski L., Elektroniczne oblicze polityki. Demokracja, państwo, instytucje polityczne $w$ okresie rewolucji informacyjnej, Uczelniane Wydawnictwa NaukowoDydaktyczne Akademii Górniczo-Hutniczej, Kraków 2004.

Portes A., Social capital: Its origins and applications in modern sociology, Annual Reviews of Sociology, 24, 1998.

Postman N., Technopol. Triumf techniki nad kultura, przeł. Tanalska-Dulęba A., Państwowy Instytut Wydawniczy, Warszawa 1995.

Postman N., Zabawić się na śmierć. Dyskurs publiczny w epoce show-businessu, przeł. Niedzielski L., Wydawnictwo Muza S.A., Warszawa 2002.

Powell W. W., Neither Market Nor Hierarchy: Network Forms of Organization, Research in Organizational Behavior, Vol. 12, 1990.

Przybyszewski R., Kapitat ludzki w procesie ksztaltowania gospodarki opartej na wiedzy, Wydawnictwo Difin, Warszawa 2007.

Przygodzki Z., Innowacyjne środowiska przedsiębiorczości w kontekście procesów organizacji i regulacji $w$ regionie [w:] Zrozumieć terytorium. Idea i praktyka, Nowakowska A. (red.), Wydawnictwo Uniwersytetu Łódzkiego, Łódź 2013.

Przygodzki Z., Region wiedzy - wiedza i kapitał ludzki a rozwój regionu [w:] Region $w$ gospodarce opartej na wiedzy. Kapitat ludzki - innowacje - korporacje transnarodowe, Nowakowska A., Przygodzki Z., Sokołowicz M.E. (red.), Wydawnictwo Difin, Warszawa 2011.

Przygodzki Z., Znaczenie kapitału ludzkiego w budowaniu innowacyjnych regionów [w:] Budowanie zdolności innowacyjnych regionów, Nowakowska A. (red.), Wydawnictwo Uniwersytetu Łódzkiego, Łódź 2009.

Putnam R. D., Demokracja $w$ działaniu: tradycje obywatelskie we współczesnych Włoszech, Instytut Wydawniczy „Znak”, Fundacja im. Stefana Batorego, KrakówWarszawa 1995.

Rheigold H., The virtual community. Homesteading on the Electronic Frontier, Cambridge, Massachusetts, 2000, Wstęp [za:] Gustowski W., Komunikacja w mediach społecznościowych, Wydawnictwo Novae Res, Gdynia 2012.

Rheingold H., Smart Mobs. The Next Social Revolution. Transfortning Cultures and Communities in the Age of Instant Access. Cambridge, Mass: Basic Books 2002 [za:] Krzysztofek K., Społeczeństwo $w$ dobie Internetu: refleksyjne czy algorytmiczne? [w:] Re: internet - spoleczne aspekty medium, Polskie konteksty i inspiracje, praca zbiorowa, Wydawnictwa Akademickie i Profesjonalne, Warszawa 2006.

Sakowicz M., Modernizacja samorzqdu terytorialnego $w$ procesie integracji Polski z Uniq Europejska, Szkoła Główna Handlowa w Warszawie, Warszawa 2007.

Śliwińska K., Dewalska-Opitek A., Gospodarka oparta na wiedzy. Stan i perspektywy rozwoju w Polsce [w:] Gospodarka oparta na wiedzy, Hejduk I.K., Korczak J. (red.), Wydawnictwo Uczelniane Politechniki Koszalińskiej, Koszalin 2006.

Słownik łacińsko-polski, Warszawa 1973 [za:] W. Gustowski, Komunikacja w mediach społecznościowych, Wydawnictwo Novae Res, Gdynia 2012.

Smith A., Teoria uczuć moralnych, Wydawnictwo Naukowe PWN, Warszawa 1989. 
Starosta P., Społeczność lokalna [w:] Encyklopedia Socjologii, t. IV, Bokszański Z. (red.), Wydawnictwo Oficyna Naukowa, Warszawa 2002.

Stavros I., Nielsen K. (ed.), Economics and the Social Sciences: Boundaries, Interaction and Integration, Edward Edgar Publishing, 2007.

Stępka P., Subda K., Wykorzystanie analizy sieci społecznych (SNA) do budowy organizacji opartej na wiedzy, e-mentor, nr 1 (28)/2009.

Strahl D. ( red.), Gospodarka lokalna i regionalna $w$ teorii i praktyce, Prace Naukowe Akademii Ekonomicznej im. O. Langego we Wrocławiu, nr 1161, Wydawnictwo Akademii Ekonomicznej im. O. Langego we Wrocławiu, Wrocław 2007.

Stryjakiewicz T., Sieciowa organizacja gospodarki a rozwój regionalny [w:] Współczesne problemy i koncepcje teoretyczne badań przestrzenno-ekonomicznych, Czyż T., Rogacki H. (red.), Biuletyn KPZK PAN, Warszawa 2005.

Stryjakiewicz T., Sieciowa organizacja gospodarki a rozwój regionalny [za:] Małecki E.J., Tootle D.M., Networks of Small Manufacturers in the USA: Creating the Embeddedness [w:] Interdependent and Uneven Development. Global-local perspectives, Conti S., Taylor M. (red.), Ashgate 1997.

Sztompka P., Socjologia. Analiza społeczeństwa, Wydawnictwo Znak, Kraków 2002.

Sztompka P., Zaufanie. Fundament społeczeństwa, Wydawnictwo Znak, Kraków 2007.

The Oxford Dictionary for the Business World, Oxford University Press, 1993.

Theiss M., Krewni - znajomi - obywatele. Kapitat społeczny a lokalna polityka społeczna, Toruń 2007

Thorelli B., Networks: Between Markets and Hierarchies, Strategic Management Journal, Vol. 7, 1986.

Trigilia C., Social capital and local development, European Journal of Social Theory, 4 (4) 2001.

Trutkowski C., Mandes S., Kapital społeczny $w$ matych miastach, Wydawnictwo SCHOLAR, Warszawa 2005.

Turowski J., Socjologia. Wielkie struktury społeczne, Katolicki Uniwersytet Lubelski, Lublin 1994.

Ustawa z dnia 24 kwietnia 2003 r. o działalności pożytku publicznego i o wolontariacie, Dz. U. 2003 Nr 96, poz. 873, Art. 3.

Walczak W., Znaczenie zaufania $w$ procesach zarzadzania kapitałem ludzkim - ujęcie wielowymiarowe, e-mentor nr 5 (47)/2012, (Dostęp: http://www.e-mentor.edu.pl/ artykul/index/numer/47/id/967).

Walczak-Duraj D., Socjologia dla ekonomistów, Polskie Wydawnictwo Ekonomiczne, Warszawa 2010.

Wallace P., Psychologia Internetu, Dom Wydawniczy Rebis, Poznań 2001.

Wellman B., Physical Place and CyberPlace: The Rise of Personalized Networking, International Journal of Urban and Regional Research 25 (2001), (Dostęp: http://homes.chass.utoronto.ca/ wellman/publications/index.html).

Williamson O.E., The Economic Institutions of Capitalism, The Free Press, New York 1987.

Woolcock M., The place of social capital in understanding social and economic outcomes, Canadian Journal of Policy Research 2001, t. 2, nr 1. 
Wronowska G., Koncepcja kapitału ludzkiego - ujęcie historyczne [w:] Teoretyczne aspekty gospodarowania, Kopycińska D. (red.), Wydawnictwo Katedra Mikroekonomii Uniwersytetu Szczecińskiego, Szczecin 2005.

Zawojski P., Monitor między nami. O byciu razem i osobno w cyberprzestrzeni [w:] Wiek ekranów: przestrzenie kultury widzenia, Gwóźdź A., Zawojski P. (red.), Wydawnictwo Rabid, Kraków 2002.

Zienkowski L. (red.), Wiedza a wzrost gospodarczy, Wydawnictwo SCHOLAR, Warszawa 2003.

Zienkowski L., Gospodarka oparta na wiedzy - mit czy rzeczywistość? [w:] Wiedza a wzrost gospodarczy, Zienkowski L. (red.), Wydawnictwo SCHOLAR, Warszawa 2003. 